\title{
DOENÇAS NA FASE DE ALEITAMENTO E PRÁTICAS DE MANEJO SANITÁRIO NA CRIAÇÃO DE BEZERRAS
}

\author{
PRE-WEANING DISEASES AND CALF HEALTH MANAGEMENT PRACTICES \\ Viviani Gomes ${ }^{1}$, Karina Medici Madureira ${ }^{2}$, José Renato Junqueira Borges ${ }^{3}$, Filipe Aguera Pinheiro ${ }^{10}$,

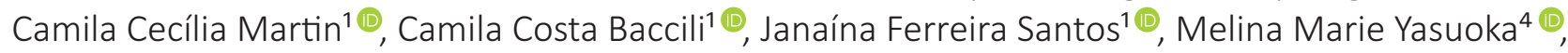 \\ Nathalia Decaris ${ }^{1}{ }^{\oplus}$, Juliana Aparecida Bombardelli ${ }^{1}{ }^{\circledR}$, Fernando José Benesi ${ }^{1+}{ }^{\circledR}$
}

- $\bigcirc$

Grupo de Pesquisa GeCria Grupo Especializado em Medicina da Produção aplicada ao Período de Transição, Cria e Recria, Departamento de Clínica Médica (VCM), Faculdade de Medicina Veterinária e Zootecnia, Universidade de São Paulo (FMVZ/USP)

Escola de Medicina Veterinária e Zootecnia, Universidade Federal da Bahia (EMEVZ/UFBA)

Faculdade de Agronomia e Medicina Veterinária, Universidade de Brasília (FAV/UnB)

Universidade Anhembi Morumbi.

Autor para correspondência: viviani.gomes@usp.br

Revista Brasileira de Buiatria Clínica Médica, Volume 1, Número 2, 2021

ISSN 2763-955X

DOI:10.4322/2763-955X.2021.002

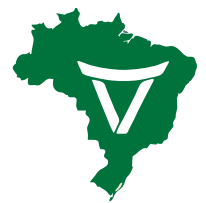

Associação Brasileira de Buiatria

\section{RESUMO}

Os desafios enfrentados pelas bezerras a partir do nascimento, como a adaptação ao ambiente extrauterino e a necessidade de obtenção das imunoglobulinas via colostro materno, aliados a um sistema imunológico ainda em desenvolvimento, tornam os bovinos jovens mais susceptíveis às doenças na fase de aleitamento, como a asfixia neonatal, diarreias, onfalopatias e broncopneumonias. A gestão sanitária na criação de bezerras é dependente da detecção precoce das doenças, definição dos principais agentes infecciosos e suas respectivas vias de transmissão, para a elaboração de protocolos terapêuticos, programas de vacinação e práticas de biosseguridade específicos. O impacto econômico das doenças é modulado por uma série de eventos que ocorrem no início da vida das bezerras, os quais resultam em altos índices de morbidade e mortalidade, baixo desempenho, atraso reprodutivo e menor produção de leite futura. Neste contexto, o objetivo deste artigo é apresentar uma ampla revisão sistemática sobre a etiologia, fisiopatologia, detecção, terapia e práticas de biosseguridade aplicadas às principais doenças que acometem as bezerras na fase de aleitamento.

Palavras-chave: asfixia neonatal, biosseguridade, broncopneumonias, diarreia, onfalopatias.

\section{ABSTRACT}

The challenges faced by dairy heifers from birth, such as adapting to the extrauterine environment and the need to obtain immunoglobulins via maternal colostrum, combined with an immune system still in development, make these animals more susceptible to diseases in the pre-weaning phase, such as neonatal asphyxia, diarrhea, navel ill and bronchopneumonia. The health management in the calf rearing system is based on the early detection of diseases, identification of the etiological agent and their respective transmission routes, for the establishment of specific therapeutic protocols and specific vaccination and biosecurity program. The economic impact of disease is modulated by a series of cascading events from birth, which results in high rates of morbidity and mortality, low performance, reproductive delay and less milk production. In this context, the aim of this paper is to present a systematic review on the etiology, physiopathology, detection, therapy and biosecurity practices applied to the main calves' diseases in the pre-weaning phase. 


\section{INTRODUÇÃO}

A fase de cria de bezerras tem um grande impacto na produtividade, uma vez que estes são os animais do rebanho mais suscetíveis às doenças, sendo o status de saúde, o manejo nutricional e o bem-estar, fatores que influenciam diretamente na produção futura ${ }^{1}$. A taxa de mortalidade de bezerras em aleitamento é de aproximadamente 5 a $6,3 \% \%^{2,3}$, sendo as principais causas a diarreia neonatal e Doença Respiratória Bovina (DRB), seguidas das inflamações umbilicais".

A morbidade por diarreia pode acometer entre 90 a $100 \%$ dos neonatos com até três semanas de idade, podendo levar a uma incidência de $3,5 \%$ a $56,4 \%$ durante o período de aleitamento ${ }^{2,4}$. No Brasil, levantamento realizado em 102 fazendas leiteiras reportou que a diarreia é a principal doença que acomete bezerras em aleitamento, com $82,8 \%$ dos casos observados nas primeiras três semanas de idade ${ }^{3}$. Além disso, animais que apresentaram diarreia possuem alta probabilidade de manifestarem $\mathrm{DRB}^{5}$, doença que pode ocasionar $24 \%$ de mortalidade em bezerras na fase de aleitamento ${ }^{2}$. Os problemas respiratórios geram alto custo com tratamento e assistência veterinária, sendo registrado nos Estados Unidos gasto anual próximo de um bilhão de dólares ${ }^{6}$. Outros estudos estimaram que os custos da DRB podem variar de US $\$ 9,84$ a US $\$ 16,35$ por bezerra durante o período de aleitamento ${ }^{7}$.

As doenças umbilicais ocupam a quarta posição, dentre as doenças que mais acometem bezerras em período de aleitamento no Brasi $1^{3}$, sendo responsável por $3 \%$ das mortes no pré-desaleitamento ${ }^{2}$. Os problemas umbilicais causam grandes perdas econômicas, uma vez que diminuem o ganho de peso e a sobrevida das bezerras, geram custos com medicamentos e assistência veterinária, aumentam a incidência de outras doenças neonatais e promovem depreciação da carcaça, podendo ainda levá-los à morte ${ }^{8}$. As inflamações umbilicais comprometem ainda o conforto e o bem-estar dos animais, que passam menos tempo deitados em decorrência das dores abdominais geradas pelo processo inflamatório?.

Considerando os impactos futuros na vida das bezerras, animais que apresentaram diarreia tiveram aumento da idade ao primeiro parto e redução na produção de leite na primeira lactação ${ }^{10}$. As lesões pulmonares irreversíveis causadas pelas broncopneumonias promoveram redução do ganho de peso diário e diminuição da produtividade na primeira lactação ${ }^{8,11}$, maior risco de não sobreviverem até um ano de vida ${ }^{12}$, além de causar aumento da idade ao primeiro parto e menor produção de leite ${ }^{7,11}$. Durante os primeiros quatro meses de vida, a diarreia ou pneumonia em bezerras promoveram impacto negativo nos teores de proteína e gordura no leite, além de menor produção na primeira lactação.

Neste contexto, o conhecimento acerca dos processos etiológicos, clínicos, terapêuticos e preventivos destas doenças é crucial para o adequado desenvolvimento de estratégias individuais e de rebanho, buscando minimizar os impactos econômicos negativos sobre a criação das bezerras em curto e longo prazo. Assim, o objetivo deste artigo é apresentar uma revisão sistemática das principais doenças que acometem as bezerras com aptidão leiteira na fase de aleitamento, em ordem cronológica, entre o nascimento e o desaleitamento, auxiliando médicos veterinários e produtores na deteç̧ão precoce e gestão das doenças no sistema de criação de bezerras.

\section{PRINCIPAIS DOENÇAS}

\section{- Adaptação e Asfixia Neonatal}

Falhas na adaptação neonatal estão associadas às maiores taxas de morbidade e mortalidade, decorrentes principalmente da asfixia neonata $1^{13}$. Durante o parto normal, com o início das contrações uterinas, ocorre a ruptura dos envoltórios fetais e do cordão umbilical, com consequente alteração na circulação 
materno-fetal. A força das contrações e a pressão sobre a região pélvica resultam em um ambiente de hipóxia fetal, com diminuição da pressão de oxigênio $\left(\mathrm{pO}_{2}\right)$ e aumento da pressão de gás carbônico $\left(\mathrm{pCO}_{2}\right)$. Nesta condição, tem-se uma alteração da perfusão uteroplacentária, com aumento do ácido carbônico, caracterizando uma acidose respiratória. Com a diminuição da $\mathrm{pO}_{2}$ nos tecidos, o organismo prioriza a oxigenação de órgãos vitais como cérebro, coração e adrenal, e o restante dos tecidos passa a depender da glicólise anaeróbia, com a produção do ácido lático e acidose metabólica. Esta acidose mista é transitória e geralmente normaliza-se entre 24 a 48 horas ${ }^{13}$.

Ao nascimento, a bezerra realiza a sua primeira inspiração profunda, com aumento do fluxo sanguíneo e das concentrações de oxigênio, com subsequente redução da resistência pulmonar e fechamento do ducto arterioso e forame oval, dando início à circulação do recém-nascido ${ }^{14}$. A hipertensão da artéria pulmonar transitória foi reportada como um processo fisiológico no período neonatal em bezerras da raça Holandesa ${ }^{15}$. Os animais com asfixia neonatal apresentam baixa $\mathrm{pO}_{2}$ e desenvolvem hipertensão da artéria pulmonar, com persistência do forame oval e ducto arterioso, especialmente em bezerras clonadas ${ }^{16}$.

A asfixia neonatal se caracteriza pela hipoxemia, hipercapnia e acidose mista, resultante da inadequada oxigenação do feto ou recém-nascido, descrita na literatura como Síndrome da Dificuldade Respiratória (SDR) ou Asfixia Perinatal ${ }^{17,18}$. A asfixia neonatal pode ser classificada conforme sua etiologia e momento de seu aparecimento, em asfixia precoce, que ocorre durante ou imediatamente após o parto, e asfixia tardia, observada nas primeiras horas de vida ${ }^{13}$.

Partos distócicos tendem a comprometer o fluxo sanguíneo materno-fetal, gerando uma intensificação da hipóxia e acidose mista no neonato, na fase pós-natal imediata. Tamanho fetal, duração do parto, anatomia pélvica materna, dilatação, dentre outros fatores, contribuem para o nascimento de uma bezerra com baixa vitalidade, que muitas vezes aspiram mecônio e com quadro clínico compatível com asfixia neonatal precoce ${ }^{19}$. A asfixia tardia ocorre nas bezerras prematuras, devido a atelectasia causada pela falta de surfactante alveolar. Os animais nascem bem, mas após dez a quinze minutos de vida já começam a apresentar dispneia progressiva e taquipneia compensatória, como forma de auxílio nas trocas gasosas. A prematuridade pode ser observada em animais com alopecia e dentes incisivos recobertos por gengiva ${ }^{20}$.

Os animais asfixiados apresentam alterações respiratórias como apneia, dispneia, sibilos, além da depressão do sistema nervoso central decorrente da acidose, observando-se redução das respostas reflexas. Ainda é possível observar mucosas esbranquiçadas ou azuladas, devido à redução da perfusão sanguínea, edema de língua, decúbito lateral, flacidez muscular e apatia $^{13}$. Estes animais, em consequência do distúrbio respiratório e baixa vitalidade, sem condições de se manterem em estação e apresentando pouco reflexo de sucção, apresentam maior risco para a falha na transferência de imunidade passiva, baixo ganho de peso e maior predisposição à outras doenças no decorrer da vida ${ }^{13}$.

O diagnóstico da asfixia intrauterina pode ser feito pelo acompanhamento dos partos distócicos e demorados, com o descolamento parcial da placenta ou exposição dos envoltórios fetais sem a evolução de parto, assim como, a presença de mecônio tingindo os líquidos fetais e ausência ou redução dos reflexos de sucção, interdigital e ocular ${ }^{13}$.

O monitoramento do parto e a avaliação da viabilidade neonatal podem auxiliar nas intervenções precoces. A vitalidade dos neonatos pode ser avaliada por meio da escala Apgar, com o objetivo de auxiliar na tomada de decisão acerca do melhor manejo inicial para os neonatos, além de definir os pacientes de risco ${ }^{21}$. A escala Apgar tradicional foi adaptada por Born ${ }^{22}$, e avalia quatro aspectos no neonato bovino: tônus muscular, irritabilidade reflexa, coloração de mucosas e 
Quadro 1.Parâmetros adotados para a avaliação da vitalidade em neonatos bovinos, segundo Born ${ }^{22}$.

\begin{tabular}{|c|c|c|c|}
\hline \multirow{2}{*}{ Critérios } & \multicolumn{3}{c|}{ Escores } \\
\cline { 3 - 5 } & 0 & 1 & 2 \\
\hline $\begin{array}{c}\text { Tônus muscular: movimentação cabeça } \\
\text { e tentativas de ficar estação }\end{array}$ & Ausente & Diminuída & $\begin{array}{c}\text { Movimentos } \\
\text { espontâneos e ativos }\end{array}$ \\
\hline Reflexo interdigital e ocular & Ausente & $\begin{array}{c}\text { Reação presente a pelo } \\
\text { menos um reflexo }\end{array}$ & $\begin{array}{c}\text { Reação aos dois } \\
\text { reflexos }\end{array}$ \\
\hline Coloração mucosas & Azulada & Esbranquiçadas & Rósea-avermelhada \\
\hline Respiração & Ausente & Irregular & Regular
\end{tabular}

Interpretação: a soma das escalas obtidas segundo os critérios de avaliação do Apgar indica o grau de vitalidade do recém-nascido: 0 a 3: pouca vitalidade, 4 a 6: deprimido e 7 a 8: boa vitalidade.

esforço respiratório (Quadro 1). A escala Apgar deve ser realizada no primeiro, quinto e décimo minutos de vida após o nascimento. Um escore Apgar baixo no primeiro minuto pode ser resultante de uma depressão temporária, enquanto o baixo escore em cinco ou dez minutos pode indicar importantes alterações fisiológi$\mathrm{cas}^{22}$.

Logo após o parto, a bezerra apresentando boa vitalidade deverá, em três minutos pós-nascimento, levantar ou movimentar a cabeça; em cinco minutos, ficar em decúbito esternal; em vinte minutos, iniciar as tentativas de ficar em estação e em sessenta a noventa minutos, estar em estação. Bezerras da raça Holandesa nascidas de partos eutócicos apresentam frequência respiratória de 50 movimentos por minuto (mpm) e frequência cardíaca de 133 batimentos por minuto (bpm) ao nascimento. Bezerras nascidas de partos distócicos apresentam $40 \mathrm{mpm}$ e $135 \mathrm{bpm}$ ao nascimento, respectivamente ${ }^{23}$.

Outra opção para o diagnóstico da asfixia neonatal em ambiente hospitalar seria o uso da hemogasometria arterial. O quadro de acidose é caracterizado quando o neonato apresenta um $\mathrm{pH}$ sanguíneo inferior a 7,2 ou excesso de bases (BE) superior a $10 \mathrm{mmol} / \mathrm{L}^{24}$. A mensuração de lactato pode indicar quadros de acidose em bezerras, quando seus valores estiverem superiores a $6,62 \mathrm{mmol} / \mathrm{L} \mathrm{e} \mathrm{pH}$ abaixo de 7,21 . Sua aferição também pode indicar a hipoperfusão de órgãos e o prognóstico do paciente ${ }^{25}$. A terapia de suporte com bicarbonato de sódio $\left(\mathrm{NaHCO}_{3}\right)$ intravenoso para correção da acidose mista é necessária nos neonatos que apresentem $\mathrm{pH}$ inferior a 7,2.

$\mathrm{O}$ cálculo utilizado é: peso corporal $(\mathrm{kg}) \mathrm{x}$ excesso de bases ( $\mathrm{mmol} / \mathrm{L}) \times 0,4(\mathrm{~L} / \mathrm{kg})$, ou seja, é multiplicado o peso do animal, pelo valor do excesso de bases obtido pela hemogasometria, e pelo fator fixo 0,4. Deve ser administrado um terço da dose calculada, reavaliar o animal com a hemogasometria e assim constatar a resposta ao tratamento ${ }^{26}$.

Os animais com baixa vitalidade após o nascimento devem ser colocados em decúbito esternal, com massagem da região torácica, aspiração do líquido das narinas, estímulos sensoriais em pontos de acupuntura (muflo e septo nasal), água fria sobre a cabeça ou orelhas, com o objetivo de estimular o início da respiração. Podem ser utilizados ainda ressuscitadores para a remoção de líquido das vias aéreas e oxigenação manual ${ }^{27}$ (Figura 1). A suspensão dos neonatos pelos membros pélvicos para a liberação das vias aéreas deve ser realizada com cuidado sem sacudir o neonato, por no máximo 

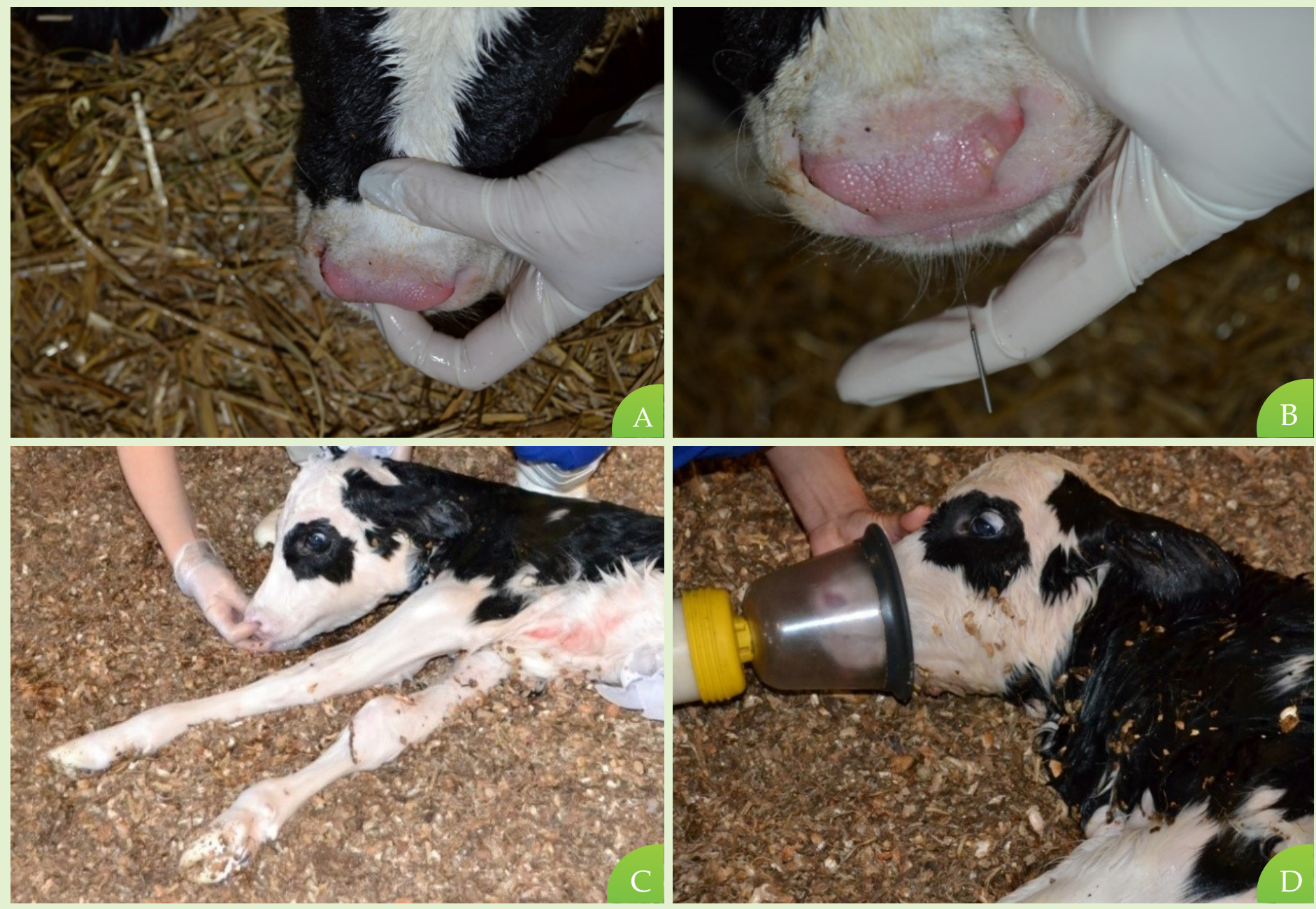

Figura 1. Estimulação da respiração em bezerros recém-nascidos: A) Pressão digital do espelho nasal,B) Utilização de agulha no centro do espelho nasal,C) Compressão do septo nasal,D) Utilização de ressuscitadores para a oxigenação dos pulmões.

noventa segundos, para evitar compressão pulmonar e possível lesão cerebral.

O uso de drogas estimulantes do centro respiratório, como cloridrato de doxapram, também é indicado para neonatos deprimidos ou com baixa vitalidade. Em bezerras recém-nascidas, o uso do cloridrato de doxapram aumentou a frequência respiratória e reduziu a $\mathrm{PaCO}_{2}$ no sangue arterial após um minuto da aplicação, aumentando o $\mathrm{pH}$ sanguíneo ${ }^{28}$. O cloridrato de doxapram não apresenta efeitos positivos em casos graves, sendo recomendada a intervenção ventilatória e oxigenoterapia.

A intervenção ventilatória imediata após o diagnóstico é primordial. A oxigenoterapia pode ser via cateter intra-nasal ou com máscaras, com volume de $5 \mathrm{a}$
6L/minuto, aumentando a disponibilidade de oxigêni$\mathrm{o}^{29}$. Técnicas de ventilação mecânica também estão descritas em bezerros clonados com hipercapnia, hipóxia e hipertensão da artéria pulmonar ${ }^{30}$. São necessários ventiladores, máscaras ou sondas naso-traqueais ou oro-traqueais (6,5 a 11mm), com pressão não excedendo 30 a $40 \mathrm{mmHg}$, e frequência ventilatória de 15 a 25 respirações por minuto. $\mathrm{O}$ monitoramento do animal com hemogasometrias seriadas é necessário para os ajustes da máquina, conforme a resposta do animal à terapia $^{31}$. Os principais modos ventilatórios utilizados na neonatologia humana são o mandatório intermitente e a pressão contínua positiva (CPAP), sendo o segundo método menos invasivo pela utilização de máscaras ${ }^{32}$. A utilização da pressão positiva no final da 
expiração (PEEP) também pode ser utilizada na ventilação mecânica, em casos de atelectasia, mantendo os gases no pulmão ao final da expiração, e com isso evitando o colabamento dos alvéolos ${ }^{33}$.

Broncodilatadores como beta-agonistas e xantinas são indicados no tratamento de apneia e hipóxia em bezerras com asfixia neonatal, como a tolazolina e aminofilina, respectivamente ${ }^{28}$, porém a eficácia destes fármacos tem sido questionada na literatura. $\mathrm{O}$ surfactante também pode ser utilizado no tratamento das asfixias em bezerras prematuras, porém com o uso limitado pelo seu alto custo ${ }^{34}$. Corticoides também apresentam resultados interessantes nas bezerras tingidas de mecônio.

As figuras 2 e 3 apresentam fluxogramas para a tomada de decisão em relação à sequência de procedi- mentos que devem ser realizados imediatamente após o nascimento, com o objetivo de aumentar as chances de sobrevida dos neonatos que evoluem para a asfixia neonatal.

Como prevenção das asfixias neonatais várias medidas podem ser adotadas, como a seleção genética de reprodutores compatíveis com as fêmeas, evitar a superalimentação das matrizes, monitoramento das fêmeas no pré-parto, intervenção no parto em casos necessários, elaboração de protocolos para assistência obstétrica, e treinamento dos colaboradores que atuam no pré-parto e maternidade. A assistência ao recémnascido imediatamente após o parto, com avaliação da vitalidade, pode auxiliar na tomada de decisões clínicas, reduzindo a mortalidade dos animais por asfixia neonatal.

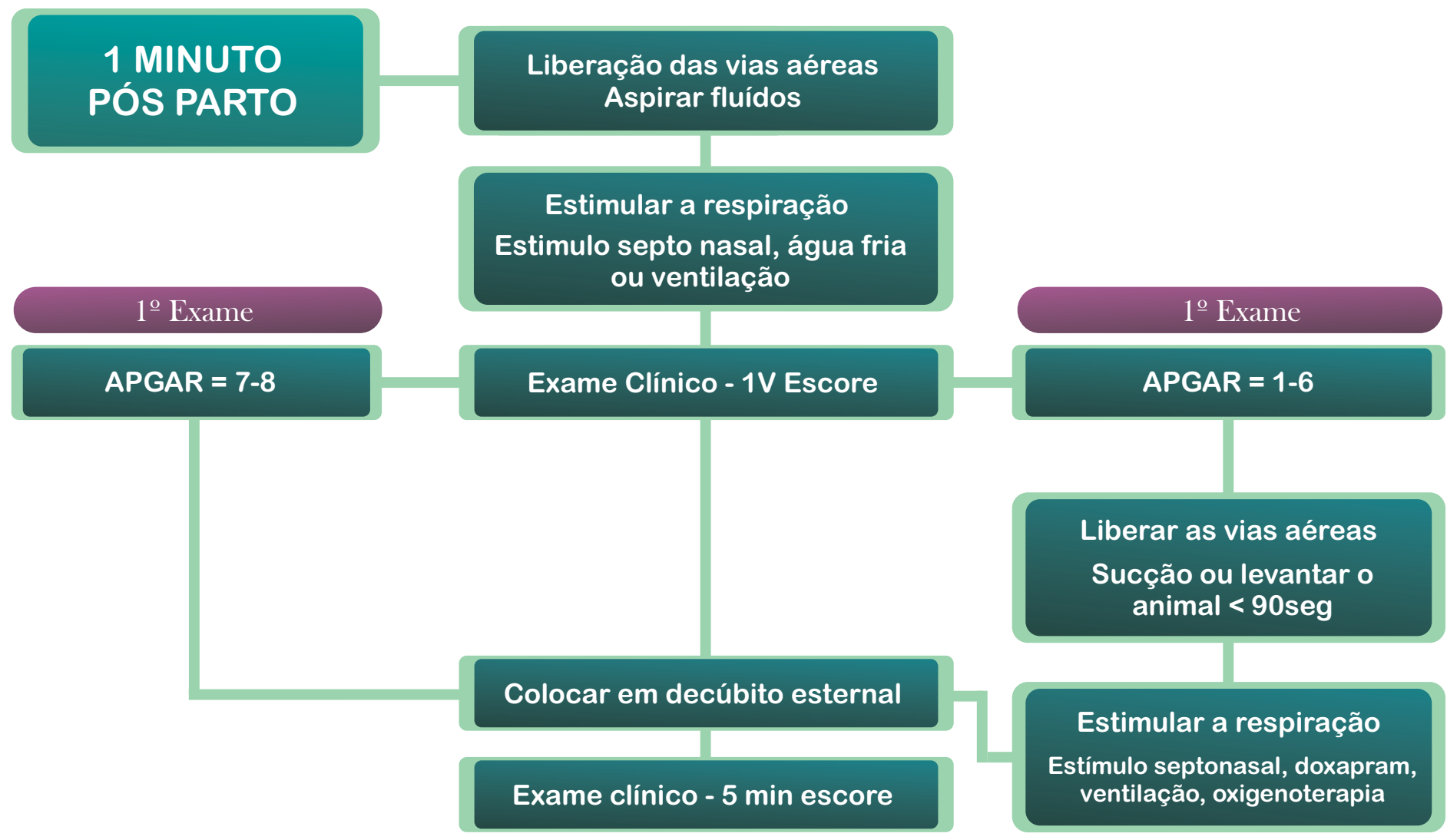

Figura 2. Avaliação dos neonatos com 1 minuto após o nascimento com o objetivo de estimular a respiração e análise do escore de vitalidade APGAR. A estimulação da respiração dos neonatos com baixa vitalidade (soma $\leq 6$ ) pode ser realizada com a liberação das vias aéreas por meio de sucção das narinas ou levantamento do neonato por um período máximo de 90 segundos. A estimulação da respiração nestes animais pode ser ainda realizada pela compressão do septo nasal (ou pelos demais métodos indicados na figura 1), uso de doxapram, ventilação e oxigenoterapia. O neonato deve ser reavaliado após 5 minutos. 


\section{MINUTOS} PÓS PARTO

\section{$2^{\circ}$ Exame Clínico}

\section{Estimular a respiração}

Estimulo septo nasal ou

ventilação

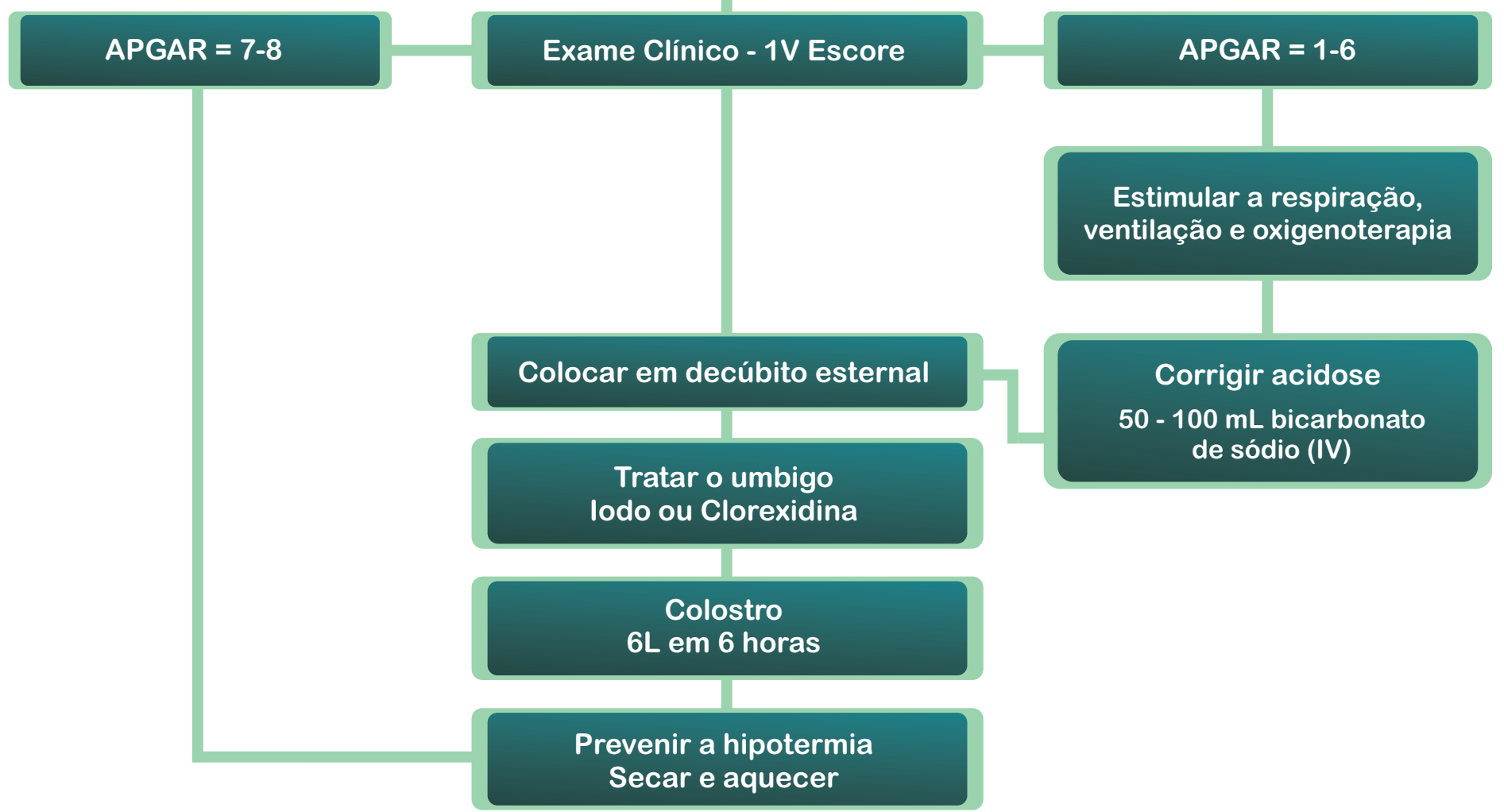

Figura 3. Reavaliação do neonato aos 5 minutos pós-nascimento. Se o animal mantiver baixa vitalidade, deve-se manter as tentativas para estimular a respiração e realizar a correção do desequilíbrio ácido básico. A partir deste momento deve-se intensificar os primeiros cuidados, com a antissepsia umbilical, manejo de colostro e prevenção da hipotermia, com o objetivo de evitar a falha na transferência de imunidade passiva e onfalopatias.

\section{- Afecções Umbilicais}

O cordão umbilical é uma estrutura funicular, responsável pela circulação materno-fetal, composto pela membrana amniótica, úraco, duas artérias que se unem às artérias ilíacas internas e duas veias que se anastomosam na entrada do cordão umbilical externo (Figura 4). A membrana amniótica é rompida no nascimento, e após cinco a trinta minutos, ocorre o rompimento do cordão umbilical, por ação da musculatura lisa e bainha peritoneal dos vasos, havendo retração imediata das artérias umbilicais para o interior do abdômen, colapso da veia e regressão do úraco, que se torna um vestígio na vesícula urinária. A veia umbilical origina o ligamento redondo do fígado e as artérias umbilicais originam os ligamentos redondo e laterais da vesícula urinária ${ }^{35}$. Em partos eutócicos, a mumificação do umbigo e sua deiscência séptica devem ocorrer em até dez dias pós-nascimento ${ }^{36}$.

A contaminação do ambiente onde a bezerra 


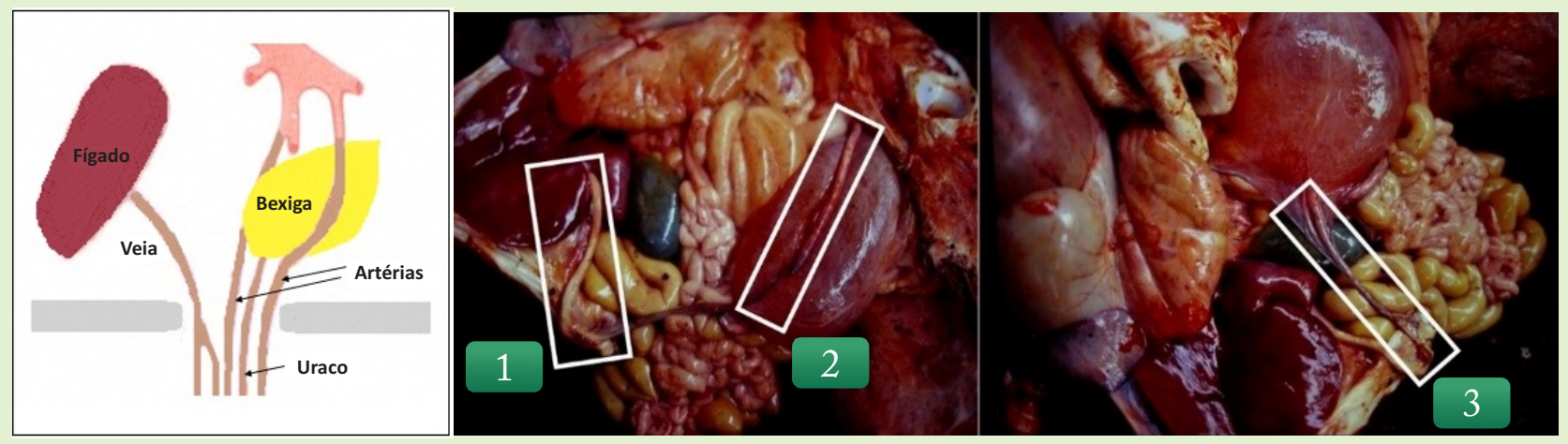

Figura 4. Modelo esquemático e imagens de necropsia ilustrando os vasos umbilicais e órgãos adjacentes em bezerros. 1: veia umbilical, 2: artéria umbilical e 3: úraco.

nasce e permanece nos primeiros dias de vida, falhas no processo de colostragem, antissepsia inadequada do cordão umbilical, traumatismos e enfermidades intercorrentes (asfixia neonatal, miíases), alterações congênitas, genéticas ou anatômicas (falhas na obliteração dos vasos umbilicais, coágulos, pontos de ruptura inadequados), estão entre os principais fatores predisponentes, isolados ou associados, das onfalopatias ${ }^{37}$. O principal fator determinante é a contaminação bacteriana, sendo a Trueperella pyogenes, Staphylococcus spp., e Streptococcus spp. agentes piogênicos causadores de abscessos, além do Bacteroides spp., Escherichia coli, Fusobacterium necrophorum, Klebsiella spp., Proteus spp., Pseudomonas spp.e Salmonella spp. ${ }^{38,39}$.

As onfalopatias compreendem os processos não infecciosos, como as hérnias, fibromas, neoplasias e o úraco patente, e os infecciosos, que ocorrem após a disseminação dos agentes patogênicos da região umbilical externa não cicatrizada, para a cavidade abdominal $^{40}$. Os processos infecciosos são classificados de acordo com a estrutura umbilical acometida, as onfalites afetam o cordão umbilical externo, que podem se apresentar na forma difusa (flegmonosa) ou circunscrita (apostematosa). Já nas onfaloflebites, além do cordão ocorre comprometimento da veia umbilical, nas onfaloarterites, das artérias umbilicais, nas onfalouraquites, do úraco, e as panvasculites envolvem o comprometimento de todas as estruturas umbilicais (Figura 5). As infecções podem evoluir ainda para a formação de abscessos no fígado, artérias ilíacas internas e úraco, ou ainda ocorrer bacteremia, com consequentes cistites, poliartrites, broncopneumonias, meningites, uveítes, endocardites, septicemia e morte ${ }^{41}$.

O monitoramento periódico do umbigo, principalmente nos dez primeiros dias de vida, é fundamental para a identificação precoce das onfalopatias. As informações obtidas na anamnese e exame físico podem indicar sinais de inflamação, drenagem de secreção purulenta, aumento de espessura e sensibilidade na região ${ }^{42}$.

$\mathrm{Na}$ forma aguda das inflamações umbilicais, os sintomas mais comuns observados na inspeção são as alterações do estado geral, como anorexia e cifose, aumento de volume e hiperemia da região umbilical/abdominal. Pode haver aglutinamento de pelos da região umbilical, em decorrência de exsudatos ${ }^{41}$. A dor, hipertermia local, aumento da tensão abdominal e espessamento dos componentes umbilicais podem ser detectados na palpação abdominal, realizada primeiramente com o animal em estação e depois em decúbito lateral ou dorsal ${ }^{42}$. Nas formas crônicas, os animais podem estar abaixo do peso e apresentarem aumento de volume e consistência firme da região umbilical, porém sem sensibilidade. Nas onfaloflebites e onfalo- 


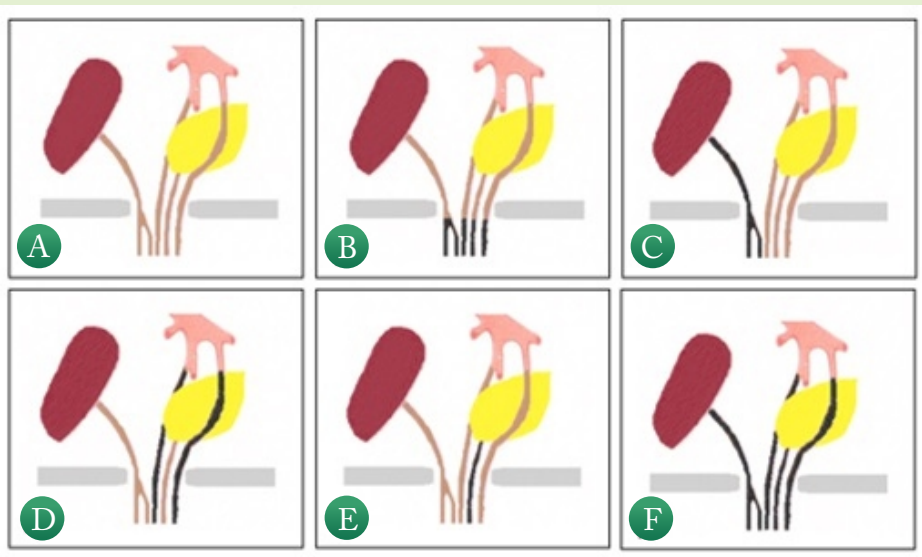

Figura 5. Modelo esquemático das alterações dos componentes umbilicais de bezerros. A: vasos normais; B: onfalite; C: onfaloflebite; D: onfaloarterite; E: onfalouraquite e F: panvasculite.

arterites pode haver toxemia associada ${ }^{41}$.

Nas hérnias umbilicais, pode-se verificar, na palpação, a presença do anel, saco e conteúdo herniário, com possibilidade de redução do saco herniário, exceto em aderências e em casos de segmentos encarcerados do omento ou intestino ${ }^{42}$. Os abscessos umbilicais podem ser confirmados após punção e eliminação de secreção purulenta e na persistência de úraco observa- se o gotejamento de urina pela região umbilical, permitindo assim a diferenciação entre estas afecções ${ }^{43}$.

A termografia pode ser também utilizada na detecção das onfalites, por ser um procedimento seguro e não invasivo, detectando diferenças de temperatura na pele de bezerras sadias e inflamadas ${ }^{44}$.

A palpação abdominal bimanual é extremamente importante para a detecção das onfalopatias, uma vez que ela pode auxiliar na identificação de alterações no calibre dos componentes umbilicais ao longo dos seus trajetos, indicando a presença de massas ${ }^{45}$. Por outro lado, a palpação torna-se difícil em animais com aumento da tensão da parede abdominal ou muito pesados ${ }^{46}$. A extensão do processo inflamatório pode ser determinada pela palpação abdominal, porém, existem casos em que a mesma pode não revelar o grau de acometimento das estruturas intraabdominais, sendo frequentemente determinada a sua real extensão e presença somente durante a cirurgia exploratória, exame necroscópico ou exame ultrassonográfico ${ }^{47}$. Recentemente foi proposto um sistema de pontuação clínica para a detecção das onfalopatias ${ }^{48}$

Quadro 2.Descrição do sistema de pontuação clínica proposto para detecção de onfalopatias.

\begin{tabular}{|c|c|c|c|}
\hline Parâmetros clínicos & Categorias & Descrição & Pontuação \\
\hline $\begin{array}{l}\text { Espessamento do coto } \\
\text { umbilical }\end{array}$ & $\begin{array}{l}\text { Presente } \\
\text { Ausente }\end{array}$ & $\begin{array}{l}\text { Diâmetro }>1,3 \mathrm{~cm} \\
\text { Diâmetro }<1,3 \mathrm{~cm}\end{array}$ & $\begin{array}{l}2 \\
0\end{array}$ \\
\hline Hipertermia local & $\begin{array}{c}>\mathrm{T}^{\circ} \mathrm{C} \\
\mathrm{T}^{\circ} \mathrm{C} \text { normal }\end{array}$ & $\begin{array}{c}\text { Temperatura do coto a partir de } 0,5^{\circ} \mathrm{C} \text { acima da } \\
\text { temperatura corporal }{ }^{*} \\
\text { Temperatura do coto de até } 0,5^{\circ} \mathrm{C} \text { acima da } \\
\text { temperatura corporal }\end{array}$ & 1 \\
\hline Pus ou abscesso & $\begin{array}{l}\text { Presente } \\
\text { Ausente }\end{array}$ & - & $\begin{array}{l}4 \\
0\end{array}$ \\
\hline Hérnia umbilical & $\begin{array}{l}\text { Presente } \\
\text { Ausente }\end{array}$ & - & $\begin{array}{l}2 \\
0\end{array}$ \\
\hline
\end{tabular}

*A mensuração da temperatura da pele deve ser medida por meio de termômetro infravermelho na região do esterno. A soma da pontuação $\geq 2$ é indicativa de onfalopatia. 
(Quadro 2).

Com relação aos exames laboratoriais, as bezerras com onfalopatias podem apresentar leucocitose por neutrofilia ${ }^{49}$ e hiperfibrinogenemia ${ }^{50}$. A mensuração da proteína plasmática total $(\mathrm{g} / \mathrm{dL})$ ou de sólidos totais séricos (\%) entre 24 e 48 horas de vida, também é importante para detectar a presença da Falha na Transferência de Imunidade Passiva (FTIP), uma vez que esta é um importante fator de risco para o desenvolvimento das afecções umbilicais.

O exame ultrassonográfico abdominal permite identificar com exatidão os componentes umbilicais internos envolvidos nas onfalopatias ${ }^{51}$. Para que esse exame seja adequadamente utilizado, é necessário o conhecimento prévio do processo fisiológico de involução umbilical ${ }^{51}$, destacando-se o aspecto ultrassonográfico dos vasos e suas alterações, quando adquirem características de ligamentos ${ }^{51}$. O posicionamento dos animais em decúbito lateral direito facilita a visualização das estruturas ${ }^{52}$, e a investigação deve ser realizada em região umbilical externa e intra- abdominal, entre a cartilagem xifoide e a pelve $e^{51}$. Podem ser usados transdutores microconvexos, convexos ou lineares, com frequências que variam de 3,5 a 10 $\mathrm{Mhz}^{53}$.

O processo de involução fisiológica dos componentes umbilicais é finalizado em torno de trinta dias pós-nascimento ${ }^{53}$, ocorrendo a redução do diâmetro das estruturas de forma contínua ${ }^{52}$, devido à proliferação de tecido conjuntivo fibroso hiperecoico nesses componentes, que assumem então características de ligamentos $^{51}$. No caso dos processos inflamatórios (Figura 6), pode haver aumento de calibre ou espessamento de parede dos componentes umbilicais, assim como alterações em sua ecogenicidade e presença de material purulento hipo ou hiperecoico no lúmen dos vasos $^{46}$. Podem ser encontrados abscessos, permeabilidade anormal das estruturas, persistência ou herniação dos componentes. Quando há material purulento em região luminal, muitas vezes não é possível reconhecer de forma clara as bordas da parede dos vasos ${ }^{53}$.

Com relação aos protocolos de tratamento,
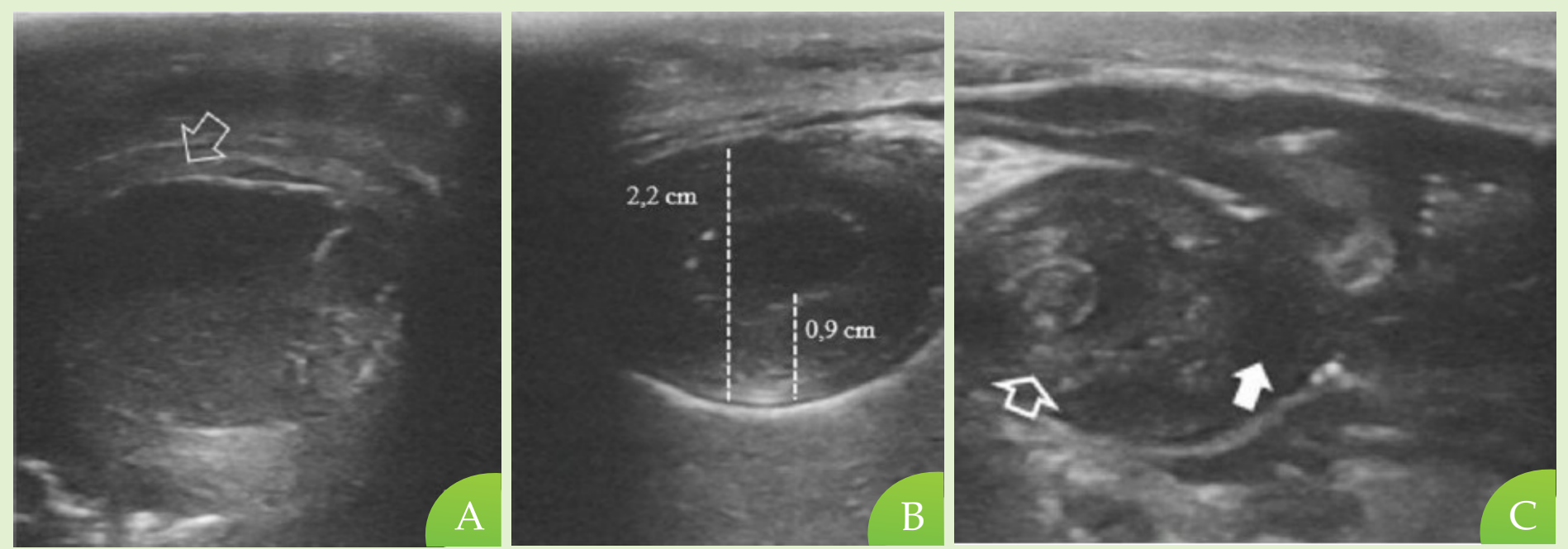

Figura 6. Imagens ultrassonográficas de região umbilical e abdominal de bezerros com até trinta dias de vida, acometidos com onfalopatias. Onfalite (A): conteúdo hipoecoico heterogêneo, com pontos hiperecogênicos, circunscrito por cápsula ecogênica (seta) sugestivo de abscesso acometendo componentes do umbigo externo. Onfaloflebite (B): veia umbilical com diâmetro de 2,2 $\mathrm{cm}$ contendo parede hipoecoica homogênea espessada $(0,9 \mathrm{~cm})$ e lúmen anecoico. Onfaloarterite $(\mathrm{C})$ : Artéria umbilical (seta sem preenchimento) com parede espessada com conteúdo ecogênico e heterogêneo. Adjacente à artéria umbilical imagem de líquido anecóico (seta preenchida) com material ecogênico e filiforme sugestivo de edema e depósito de fibrina. Ultrassom M5Vet (Mindray Medical Brazil Limited) e transdutor linear, com frequência de 7,5 MHz. 
devem ser considerados o grau de comprometimento das estruturas umbilicais, presença de sintomas locais ou sistêmicos e a classificação das onfalopatias. A utilização de antissépticos e antimicrobianos é recomendada, porém dificilmente ocorre a cura nos casos onde a afecção já está instalada, sendo necessária muitas vezes a extirpação cirúrgica completa das estruturas associadas. No caso das onfalites, pode-se realizar drenagem do abscesso e limpeza local com soluções antissépticas, além de terapia antimicrobiana e anti-inflamatória ${ }^{54}$. Nas onfaloflebites, a terapia parenteral com antimicrobianos geralmente não é bem-sucedida, sendo necessária a administração por períodos prolongados, além da frequente necessidade de laparotomia exploratória e remoção cirúrgica do abscesso. Reis ${ }^{39}$ verificou que os agentes bacterianos isolados dos componentes umbilicais infeccionados foram resistentes à cefalexina, clindamicina, enrofloxacina, tetraciclina, benzilpenicilina, trimetro$\mathrm{pim} /$ sulfametazol, ampicilina e oxacilina.

Os abcessos hepáticos grandes geralmente são incuráveis, a menos que sejam removidos cirurgicamente. Para as onfaloarterites e onfalouraquites, o tratamento geralmente consiste na remoção cirúrgica do abscesso ${ }^{55}$. Hérnias consideradas simples, com até três dedos de diâmetro e anel herniário firme e facilmente palpável, podem ser tratadas à campo, já as hérnias maiores necessitam de ambiente hospitalar e utilização de telas. No pós-operatório pode-se realizar, além do tratamento tópico da ferida cirúrgica, a terapia antimicrobiana parenteral (associação de benzilpenicilina procaína e sulfato de dihidroestreptomicina) e flunixin meglumine ${ }^{56}$. $\mathrm{O}$ úraco patente deve ser tratado cirurgicamente ou então realizado tratamento medicamentoso até que o animal alcance peso suficiente para o abate ${ }^{42}$.

Os protocolos de antissepsia visam a cicatrização e a deiscência do coto umbilical, além de prevenir infecções. A porção extra-abdominal do cordão umbilical deve ser seccionada naturalmente após o nascimento, ou realizando-se o corte quando necessário, mantendo um coto umbilical de aproximadamente cinco centímetros de comprimento ${ }^{57}$, utilizando materiais estéreis e embebendo-o em solução antisséptica por vinte segundos, antes do corte. Após o corte, o coto umbilical deverá permanecer por aproximadamente um minuto embebido na solução antisséptica, utilizando um frasco de boca larga (Quadro 3), e trocando a solução sempre que houver turvação ou sujidades $^{36}$, ou copos aplicadores sem retorno, utilizados em pré e pós-dipping em vacas leiteiras.

Apesar das vastas e conflitantes recomendações acerca dos protocolos de antissepsia do umbigo, poucos dados concretos oriundos de pesquisas existem até o momento. A escolha do antisséptico ideal para bezerras ainda é objeto de estudos, sendo o iodo e clorexidina os mais utilizados ${ }^{58}$. Em humanos, soluções de iodo a $7 \%$ promoveram queimaduras na pele ${ }^{59}$, e o iodo a $10 \%$ ocasionou onfalite iatrogênica ${ }^{60}$. A clorexidina é eficaz na presença de matéria orgânica, possui grande espectro de ação contra bactérias gram-positivas e negativas, longa duração, baixa toxicicidade e não irrita a pele como as soluções de iodo ${ }^{61}$.

Nos últimos anos, novas soluções antissépticas vêm sendo testadas, como o citrato trisódico a $10 \%{ }^{62}$ e o peptídeo antibacteriano natural nisina ${ }^{40}$, visando alternativas de prevenção das onfalopatias e substituição da solução de iodo 7\%, em decorrência das restrições estaduais americanas ${ }^{58}$. Contudo, não foram observadas diferenças na eficácia destas soluções, em comparação às já utilizadas nos rebanhos.

Analisando as informações disponíveis na literatura, podemos concluir que não existe até um momento, um protocolo único de antissepsia umbilical que seja considerado 100\% eficaz. O sucesso da prevenção das onfalopatias deve envolver a intensa atenção a todos os fatores predisponentes e determinantes, lembrando que a antissepsia do cordão umbilical, associada à higiene das instalações e à boa colostra- 
Quadro 3. Protocolo de antissepsia umbilical em bezerras recém-nascidas.

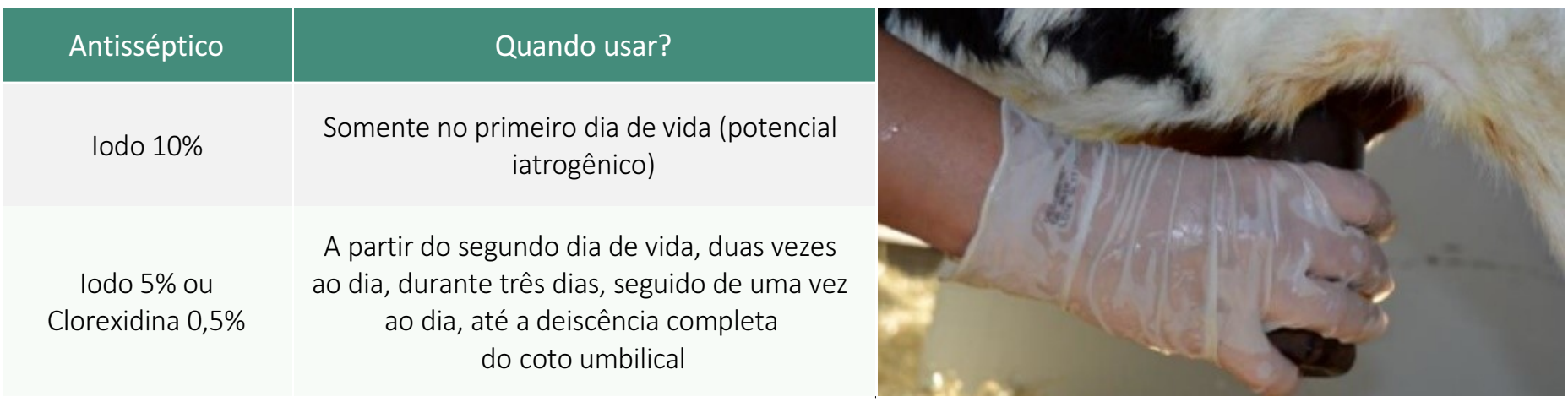

gem, são as estratégias mais importantes para a prevenção das afecções umbilicais ${ }^{63}$. Um modelo de protocolo de antissepsia umbilical está apresentado no Quadro 3.

Atenção especial deve ser dada à avaliação e cuidados com o umbigo em bezerras oriundas das biotecnologias de reprodução, como a fertilização in vitro (FIV) e a clonagem. Acredita-se que falhas no desenvolvimento das membranas córioalontóide e dos vasos sanguíneos, e alterações na morfologia e quantidade dos placentomas resultam em vasos umbilicais mais calibrosos, proporcionando o sangramento excessivo do cordão umbilical ${ }^{64}$. Desta forma, estes animais muitas vezes necessitam de ligaduras ou grampos estéreis, que impedem a drenagem do sangue acumulado no umbigo, aumentando as predisposições às infecções ${ }^{50}$, assim, os autores recomendam que, nestes casos, os grampos permaneçam por poucas horas após o nascimento, apenas enquanto houver sangramento.

\section{- Diarreias}

A diarreia é caracterizada pelo aumento da frequência de evacuações e redução na consistência das fezes ( $<15 \%$ de matéria seca), sendo uma consequência da inflamação da mucosa do intestino delgado.

Dentre os principais agentes está a Escherichia coli enterotoxigênica (K99 ou F5), bactéria Gramnegativa, responsável por 15,6 a 28,5\% dos casos de diarreia, principalmente em bezerras com idade inferi- or a cinco dias ${ }^{65}$. Salmonella entérica é outra bactéria Gram-negativa capaz de colonizar o intestino e causar diarreia em bezerras entre duas a seis semanas de idade (16,4 a 43,7\%), destacando-se pelo seu potencial zoonótico. Os sorovares $S$. typhimurium e $S$. dublin são os mais importantes, pois causam sintomas agudos e doença diarreica sistêmica, respectivamente ${ }^{66}$. O Rotavírus grupo A é considerado um agente etiológico primário da diarreia neonatal ${ }^{67}$, correspondendo a $95 \%$ dos casos em animais de até três semanas de idade ${ }^{68}$. O Coronavírus também afeta bezerras, principalmente nas primeiras três semanas de vida, com pico entre sete a dez dias e frequência de infecção entre 3,1 a $21,6 \%{ }^{69,70}$. O Cryptosporidium parvum é um protozoário intracelular obrigatório e zoonótico, podendo afetar 100\% dos animais entre sete a 21 dias de idade ${ }^{71}$. Outros agentes podem ser encontrados com menor frequência, especialmente na fase neonatal, como o Clostridium perfringens, Eimeria spp., Giardia spp., Norovirus, Nebovirus, Enterovirus e Torovirus bovino. Infecções mistas por esses agentes são frequentes ${ }^{72}$.

A infecção por microrganismos que causam diarreia geralmente ocorre no intestino delgado, concentrando-se no jejuno e íleo. Nos casos de coronavirose, a infecção inicia-se no intestino delgado proximal e pode avançar até o cólon ${ }^{73}$. A E. coli spp. e Salmonella spp. se fixam nas células das vilosidades intestinais, porém a Salmonella spp. é mais invasiva, capaz de invadir os enterócitos e migrar até os linfonodos por via 
linfática, em seguida infecta os fagócitos mononucleares, para posterior distribuição no organismo por via sanguínea, o que caracteriza a bacteremia. A disenteria causada pela Salmonella spp. é decorrente da enterocolite, que leva a má digestão e má absorção, e em menor proporção por mecanismos secretórios ${ }^{66,73}$. A E. coli spp. produz toxinas, principalmente a enterotoxina termoestável (STa), que aumenta a secreção de cloreto pelo intestino e influxo de água por alterações na osmolaridade, culminando em diarreia secretória ${ }^{69,73}$.

A Criptosporidiose leva à diarreia pela invasão dos esporozoítos no ápice das células intestinais. A infecção leva à perda das microvilosidades e encurtamento das células epiteliais colunares, com fusão e atrofia vilosa grave e subsequente hiperplasia das células da cripta. Este processo resulta em diarreia por má digestão e má absorção ${ }^{74}$.

O Rotavírus e o Coronavírus têm predileção por células maduras da vilosidade intestinal, mas enterócitos da cripta também podem ser afetados pelo Coronavírus. Os vírus se ligam e entram nas células, onde se replicam com posterior destruição e desprendimento celular. A redução na produção de enzimas hidrolíticas produzida pelos enterócitos maduros leva ao acúmulo de carboidratos (lactose) e glicose no lúmen intestinal, que exercem uma pressão osmótica, levando ao acúmulo de fluido. A infecção viral causa atrofia das vilosidades, culminando em diarreia por má digestão e má absorção ${ }^{69,73}$.

A diarreia é o principal sintoma relacionado aos distúrbios absortivos e secretórios do intestino. De maneira geral, a diarreia pode ser leve à intensa, a depender do grau de acometimento do animal e pode ser classificada em escores de 0 a 3 , de acordo com a consistência das fezes ${ }^{27}$ (Quadro 4). A coloração das fezes varia entre tons de amarelo, apresentando algumas variações de acordo com o agente etiológico.

Em casos de Salmonelose e em infecções graves pelo Coronavírus, as bezerras podem apresentar disenteria, caracterizada por fezes com presença de fibrina e coágulos de sangue (enterocolite mucohemorrágica $)^{75,76}$. A Eimeriose ocorre após quinze dias de vida, sendo mais comum em animais de dois a três meses de idade, provoca diarreia muitas vezes com sangue vivo e é comum a presença de tenesmo, que pode ocorrer também na Salmeonelose. Diarreia por Rotavírus geralmente apresenta muco abundante e não contém sangue ${ }^{72}$.

Os quadros graves de diarreia podem apresentar complicações como hipertemia, associada às infecções bacterianas por E. coli spp. ou Salmonella spp., graus variáveis de desidratação, hipotermia e alterações eletrolíticas, principalmente em relação à concentração plasmática dos íons sódio, potássio, cloro e bicarbonato de sódio $^{77,78}$. Todas essas alterações podem levar a depressão, diminuição do reflexo de sucção, fraqueza, dificuldade de permanecer em estação e em casos graves, morte. Alterações neurológicas podem ser observadas e estão frequentemente associadas à acidose metabólica, devido ao aumento da fermentação bacteriana de carboidratos no trato gastrointestinal e produção de D-lactato ${ }^{73,75}$. Bezerras com salmonelose podem apresentar alterações respiratórias e bacteremia manifestada por poliartrite, meningite ou uveíte ${ }^{76,79}$.

A história clínica, características da diarreia e idade da bezerra podem ser ferramentas importantes para o diagnóstico, auxiliando na inclusão e exclusão de agentes infecciosos ${ }^{80}$. O diagnóstico etiológico deve ser feito para nortear os protocolos terapêuticos e preventivos das propriedades. Com exceção da Salmonella spp., o Rotavírus, Coronavírus, Cryptosporidium spp. e a $E$. coli spp. podem ser encontrados em animais com fezes normais, dificultando o diagnóstico etiológico ${ }^{70,81}$.

A pesquisa de agentes bacterianos pode ser realizada por meio de cultura fecal, ELISA, teste de aglutinação, PCR convencional e PCR em tempo real. Como a E. coli spp.é considerada uma bactéria comensal, seu simples isolamento não tem significado diag- 
Quadro 4. Escores de fezes para detecção de diarreia em bezerras, adaptado de McGuirk ${ }^{27}$.

\section{Parâmetros}

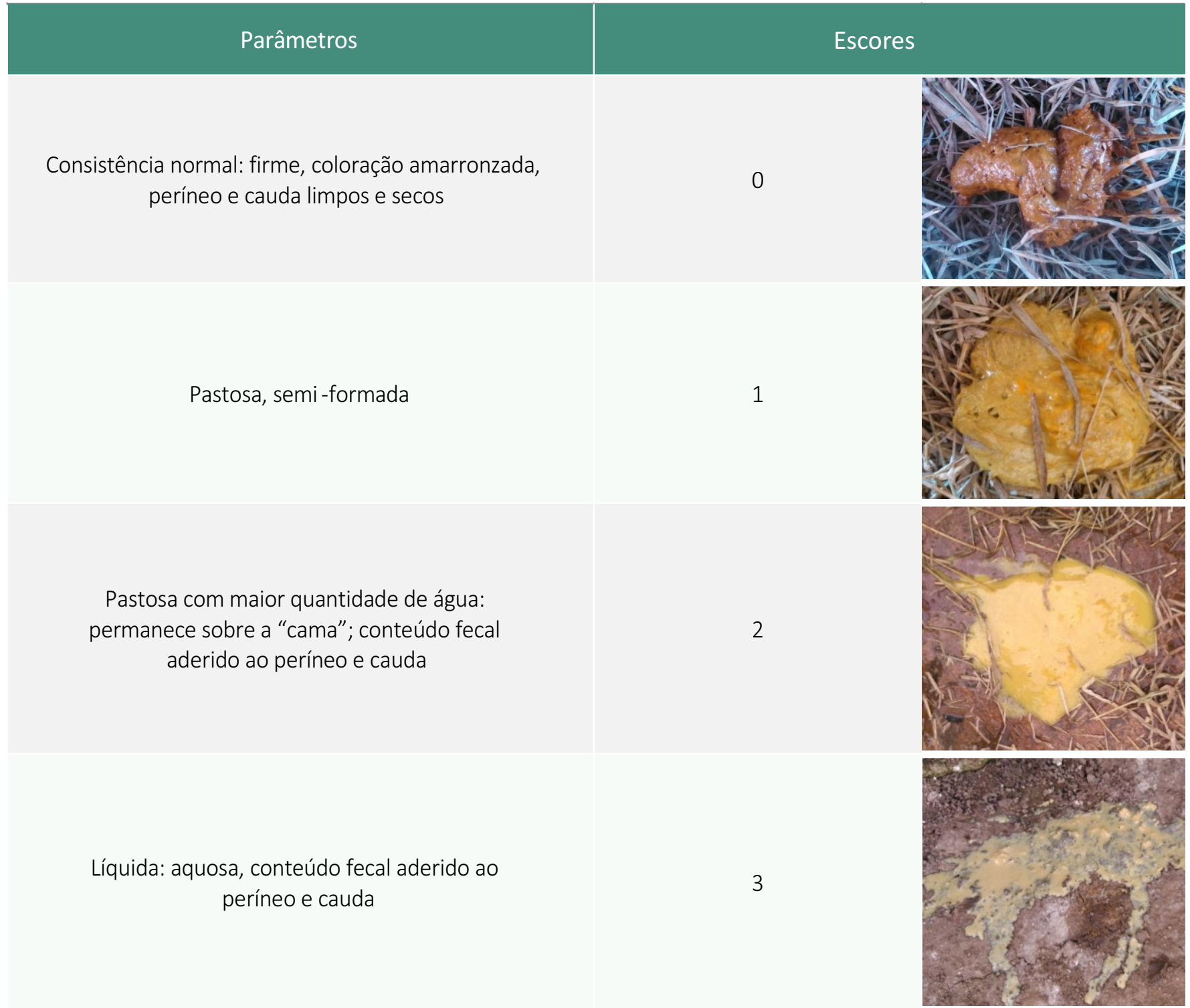

Legenda: bezerras apresentando escore fecal 0 e 1 são consideradas normais; animais com fezes de escores 2 ou 3 são considerados positivos para a diarreia neonatal.

nóstico, sendo necessária a pesquisa de fatores de virulência por $\mathrm{PCR}^{80,82}$. O isolamento da Salmonella spp. muitas vezes é dificultado pelo transporte e intervalo entre coleta e processamento da amostra, apresentando frequentemente resultados falsos negativos. Para melhor isolamento, as amostras devem ser coletadas e mantidas em meio de enriquecimento SelenitoCistina-Novobiocina (SCN), Tetrationato de Sódio ou Rapapport-Novobiocina (RVN), sendo o primeiro, o meio que apresenta melhor resultado de isolamento ${ }^{83}$. As amostras devem ser semeadas rapidamente a partir do meio enriquecido em meios específicos para Salmonella spp., como ágar SS (Salmonella-Shiguella), ágar de Hektoen e ágar Xilose Lisina Tergitol 4 (XLT4) ${ }^{65,67}$.

O diagnóstico dos agentes virais pode ser realizado por ensaios de PCR convencional, PCR em tempo real, ELISA de captura de antígeno, imunocromatografia, microscopia eletrônica, ensaio de hemaglutinação, cultura e isolamento viral, sendo a PCR a principal forma de diagnóstico. Todos esses testes são feitos em laboratórios especializados e apresentam custo elevado. $\mathrm{O}$ diagnóstico da criptosporidiose pode 
ser feita pelo teste de flotação fecal e microscopia direta, esfregaço e coloração das fezes, ELISA, PCR convencional e PCR em tempo reall ${ }^{72,80}$.

Necropsia e exame histopatológico também podem auxiliar no diagnóstico, pela detecção de lesões nos tecidos associados aos agentes. A necropsia também permite a coleta de material para o diagnóstico laboratorial dos agentes diarreicos ${ }^{73,80}$. Em infecções entéricas por Salmonella spp.é comum encontrar várias alterações macroscópicas, como a formação de pseudomembrana na mucosa do intestino delgado, hemorragia, necrose e linfonodos mesentéricos aumentados. Bezerras com septicemia por Salmonella spp. geralmente apresentam hepatomegalia, esplenomegalia, hemorragia renal e pulmonar, um tampão de fibrina e bile pode ser observado na vesícula biliar e é patognomônico para septicemia por este agente ${ }^{80}$. Nos casos de coronavirose, podem ser visualizadas úlceras necróticas branco-avermelhadas na superfície do cólon, os gânglios linfáticos podem apresentar congestão e ede$\mathrm{ma}^{69,84}$.

Microscopicamente, em infecções por $E$. coli spp. é possível observar, em seções do íleo, bastonetes gram-negativos inserindo-se na borda em escova das células das vilosidades intestinais, geralmente há pouca inflamação ${ }^{80}$. Em bezerras infectadas por Cryptosporidium spp. é possível observar os coccídeos dentro da borda vilosa do intestino, vilosidades com atrofia grave, ruptura da barreira epitelial do intestino e hiperplasia das células da cripta ${ }^{69}$. Bezerras com Rotavírus podem apresentar edema nos linfonodos mesentéricos e placas de Peyer, fusão e descamação de enterócitos do íleo, ingurgitamento do plexo capilar e infiltração de células mononucleares na lâmina própria. Nos casos de coronavirose, o íleo pode apresentar descamação e a lâmina própria pode apresentar infiltração de células mononucleares e hemorragia. Todas essas alterações observadas em infecções virais culminam na atrofia das vilosidades e necrose da lâmina própria ${ }^{69,84}$.

A análise em conjunto dos métodos de diag- nóstico é fundamental para o estabelecimento da etiologia das diarreias. O exame necroscópico e histopatológico não devem ser negligenciados pelo clínico, pois caracterizam as lesões macro e microscópicas, às quais sugerem o agente infeccioso.

O Quadro 5 indica o tipo de amostra clínica e métodos de diagnósticos disponíveis para a detecção dos principais microrganismos causadores da diarreia neonatal.

A prioridade da terapia das diarreias é a correção da desidratação, hipoglicemia, acidose e desequilíbrio eletrolítico, por meio de fluidoterapia ${ }^{85}$, que tem como objetivo manter o equilíbrio de fluidos e eletrólitos, restaurar o volume sanguíneo e perfusão tecidual, além da prevenção e tratamento do choque. A administração de fluidos pode ser feita pela via oral, em casos onde a desidratação seja de até $8 \%$, com o objetivo de restaurar a hidratação, corrigir a acidose metabólica, reverter a hipercloremia relativa e a hiponatremia. Para isso, as soluções eletrolíticas orais devem conter um agente alcalinizante, como bicarbonato e acetato, eletrólitos, principalmente sódio para normalizar os déficits no fluido extracelular, dois ou mais agentes como acetato, propionato ou glicina, que auxiliam a absorção de sódio e água pelo intestino e uma fonte de energia, como a glicose ${ }^{86,87}$.

Em animais com mais de 8\% de desidratação, nos casos de depressão, anorexia por mais de 24 horas, hipotermia, incapacidade de se manterem em estação, choque hipovolêmico e marcantes desequilíbrios eletrolíticos e ácido-base, recomenda-se a fluidoterapia por via intravenosa (IV). As soluções utilizadas para fluidoterapia IV podem ser cristaloides, como o ringer simples, ringer com lactato, glicose a 5\% e solução salina $(\mathrm{NaCl} 0,9 \%)$, colóides como plasma, sangue total, substitutos do sangue e polímeros de glicose de alto peso molecular, ou soluções hipertônicas. Também podem ser utilizadas soluções com bicarbonato de sódio $\left(\mathrm{NaHCO}_{3}\right)$, principalmente em casos de acidose 
Quadro 5.Métodos de deteç̧ão e tipo de amostra para o diagnóstico de microrganismos causadores de diarreia neonatal em bezerras.

\begin{tabular}{|c|c|c|}
\hline Microrganismos & Amostras & Métodos de diagnóstico \\
\hline Escherichia coli K99 (F5) & $\begin{array}{l}\text { Swab em meio de cultura Stuart } \\
\text { (Refrigerado } 4 \text { a } 8^{\circ} \mathrm{C} \text { ) } \\
\text { Necropsia (porções e conteúdo do íleo e } \\
\text { porções do colon) }\end{array}$ & $\begin{array}{c}\text { Cultura, Reação em cadeia de polimerase } \\
\qquad(P C R), \text { ELISA antígeno e exame } \\
\text { histopatológico }\end{array}$ \\
\hline Salmonella & $\begin{array}{l}\text { Swab em meio de transporte Tetrationato } \\
\text { (Refrigerado } 4 \text { a } 8^{\circ} \mathrm{C} \text { ) } \\
\text { Necropsia (porções do intestino e tecidos) }\end{array}$ & $\begin{array}{c}\text { Cultura, Reação em cadeia de polimerase } \\
\text { (PCR), ensaio imunocromatográfico e } \\
\text { exame histopatológico }\end{array}$ \\
\hline Rotavírus & $\begin{array}{c}\text { Fezes (Congelado }-20^{\circ} \mathrm{C} \text { ) } \\
\text { Necropsia (porções do intestino delgado) }\end{array}$ & $\begin{array}{c}\text { Reação em cadeia de polimerase (PCR), } \\
\text { ELISA antígeno, microscopia eletrônica, } \\
\text { Imunofluorescência, exame } \\
\text { histopatológico }\end{array}$ \\
\hline Coronavírus & $\begin{array}{c}\text { Fezes (Congelado }-20^{\circ} \mathrm{C} \text { ) } \\
\text { Necropsia (porções do íleo e cólon) }\end{array}$ & $\begin{array}{c}\text { Reação em cadeia de polimerase (PCR), } \\
\text { ELISA antígeno, microscopia eletrônica, } \\
\text { Imunofluorescência, exame } \\
\text { histopatológico }\end{array}$ \\
\hline Cryptosporidium & $\begin{array}{c}\text { Fezes (Refrigerado } 4 \text { a } 8^{\circ} \mathrm{C} \text { ) } \\
\text { Necropsia (porções do intestino) }\end{array}$ & $\begin{array}{c}\text { Reação em cadeia de polimerase (PCR), } \\
\text { ELISA antígeno, coloração ácido-resistente } \\
\text { em esfregaço direto, flutuação em solução } \\
\text { saturada de sacarose, exame } \\
\text { histopatológico }\end{array}$ \\
\hline Helmintos & $\begin{array}{c}\text { Fezes (Refrigerado } 4 \text { a } 8^{\circ} \mathrm{C} \text { ) } \\
\text { Necropsia (porções do abomaso e intestino) }\end{array}$ & $\begin{array}{c}\text { Contagem de ovos por grama de fezes } \\
\text { (OPG), coprocultura, exame } \\
\text { histopatológico. }\end{array}$ \\
\hline Eimeria & $\begin{array}{l}\text { Fezes (Refrigerado } 4 \text { a } 8^{\circ} \mathrm{C} \text { ) } \\
\text { Necropsia (porções do cólon) }\end{array}$ & $\begin{array}{c}\text { Contagem de oocistos por grama } \\
\text { de fezes (OOPG), exame } \\
\text { histopatológico. }\end{array}$ \\
\hline
\end{tabular}

metabólica e glicose em casos de hipoglicemia ${ }^{88}$.

O objetivo do tratamento medicamentoso da diarreia consiste em prevenir ou tratar a bacteremia e septicemia, reduzir o número de bactérias coliformes no abomaso e intestino delgado e fornecer analgesia, reduzindo assim o estresse das bezerras, o que pode ser alcançado com o uso de antimicrobianos e antiinflamatórios. O uso de antimicrobianos é essencial em casos de infecção por E. coli spp. e Salmonella spp., no entanto, existem algumas divergências sobre a recomendação do uso de antimicrobianos, independente do agente envolvido ${ }^{89,90}$.

Bezerras com diarreia apresentando sintomas sistêmicos apresentam crescimento excessivo de bactérias (E. colispp.) no intestino delgado, independente do agente etiológico que iniciou a diarreia. Por isso, anti- 
microbianos devem ser administrados em todas as bezerras que apresentarem doença clínica sistêmica, como desidratação, letargia, inapetência, pirexia ou fezes com sangue e presença de muco.

A escolha do antimicrobiano não deve ser baseada em cultura bacteriana e testes de sensibilidade, uma vez que esses testes não foram validados para bezerras com diarreia, e as bactérias presentes nas fezes não refletem de maneira precisa as populações de bactérias do intestino delgado. A eficácia do antimicrobiano deve ser avaliada pela resposta ao tratamento ${ }^{91,92}$. O antimicrobiano a ser escolhido deve ser excretado na sua forma ativa pela bile, resultando em um melhor efeito antimicrobiano local. Os antimicrobianos de primeira escolha são amoxicilina, ampicilina e sulfonamidas, como segunda escolha é recomendado o uso de ceftiofur e cefquinoma, e as fluoroquinolonas são os antimicrobianos de última escolha ${ }^{91}$.

A administração de anti-inflamatórios não esteroides, como meloxicam e flunixina meglumina, pode ser útil para reduzir a inflamação intestinal, melhorando a endotoxemia e septicemia causadas pela translocação de bactérias pelo epitélio intestinal danificado, reduzindo as cólicas intestinais e a dor abdominal, por seus efeitos analgésicos ${ }^{91}$. Usar os antiinflamatórios com cautela nos animais desidratados pelo risco de lesão renal. Em casos de infecções virais, o tratamento se baseia na terapia de suporte e no controle dos sintomas, já que não existe tratamento específico contra esses agentes. Nas diarreias por Cryptosporidium, a halofuginona parece ser eficaz na redução da duração e gravidade ${ }^{92,93}$.

Outros tratamentos que incluem o uso de corticosteróides, protetores de mucosa e adsorventes não são recomendados para o tratamento de bezerras com diarreia, pois não existem evidências concretas que mostrem a eficácia desses medicamentos. Redutores de motilidade também não devem ser utilizados, uma vez que a manutenção da mesma é importante para auxiliar na eliminação das toxinas e bactérias presentes no lúmen intestinal ${ }^{91}$.

Para prevenção da diarreia é imprescindível a transferência adequada de imunoglobulinas maternas pela colostragem e a adoção de práticas de biosseguridade nos bezerreiros. Deve ser adotado um protocolo rigoroso de limpeza e desinfecção dos utensílios e instalações após a troca de lote de $\operatorname{animais}^{94,95}$.

\section{- Broncopneumonias}

A Doença Respiratória dos Bovinos (em inglês, Bovine Respiratory Disease - BRD) é um termo genérico, o qual contempla um conjunto de doenças que pode acometer tanto o trato respiratório superior (cavidade nasal, laringe e faringe), como as rinotraqueítes, assim como doenças do trato respiratório inferior (traqueia, brônquios, bronquíolos e parênquima pulmonar), como as broncopneumonias. Broncopneumonia é definida como uma inflamação do parênquima pulmonar, geralmente acompanhada de inflamação nos bronquíolos e frequentemente de pleurite.

A BRD é mais frequente em bezerras entre a quarta e oitava semanas de vida, sendo reportada incidência nacional em torno de $23,4 \%$ na fase prédesaleitamento $^{96}$. Dados globais levantados pelo USDA reportam que as doenças respiratórias são responsáveis por $24 \%$ das mortes no período de aleitamento e 58,9\% em animais após o desaleitamento ${ }^{2}$.

A broncopneumonia é uma doença multifatorial, cujos fatores predisponentes estão relacionados ao hospedeiro, ambiente e manejo. Em relação ao hospedeiro, os livros e revisões bibliográficas clássicas de anatomia $^{97}$, fisiologia ${ }^{98}$, imunologia ${ }^{99}$ e semiologia ${ }^{100}$ descrevem particularidades para os bovinos às quais serão reportadas nesta seção. Em relação às particularidades anatômicas, o pulmão esquerdo dos bovinos é dividido em lobo cranial (porção cranial e caudal) e lobo caudal, enquanto que o pulmão direito é maior que o esquerdo, e além dos lobos cranial e caudal, possui o lobo médio. Os lobos pulmonares são separados por 
tecido conjuntivo, o qual se prolonga para o interior do parênquima pulmonar e os divide em segmentos.

O trato respiratório dos bovinos possui um sistema de defesa altamente complexo para prevenir às infecções por vírus e bactérias. Toda a superfície aérea, desde narinas até brônquios, é revestida por tecido mucociliar. $\mathrm{O}$ ar quando passa pelas narinas sofre um turbilhonamento e as partículas maiores que $20 \mu \mathrm{m}$ ficam retidas na mucosa das narinas, faringe e traqueia. As partículas com tamanho entre 20 a $5 \mu \mathrm{m}$ se estabelecem nos brônquios e bronquíolos, e as partículas menores que $5 \mu \mathrm{m}$ podem alcançar os alvéolos, onde serão capturadas e destruídas pelos macrófagos alveolares. As partículas aderidas na camada mucosa são transportadas em direção à faringe para serem deglutidas, por meio do batimento ciliar. Os bovinos ainda possuem vias aéreas estreitas, o que determina fluxo de ar e fluidez do muco produzido pelo aparelho mucociliar mais lentos.

Os bovinos possuem caixa torácica rígida e árvore brônquica longa, o que implica em ventilação dependente do diafragma e da atividade ventilatória basal. Estas particularidades em conjunto resultam em menor capacidade de troca gasosa e baixa tensão de oxigênio bronquiolar ou alveolar, com consequente diminuição da atividade fagocitária dos macrófagos mucociliares e alveolares, com redução do processo de depuração pulmonar.

Em relação à resposta imune, as bezerras nascem agamaglobulinêmicas e com sistema imune adaptativo naive, pois o sistema placentário protetor impede a estimulação antigênica do feto durante a gestação. Assim, o amadurecimento do sistema imune adaptativo das bezerras é um processo lento e gradual que ocorre entre o nascimento e a puberdade, de acordo com os desafios antigênicos na fase pós-natal. Desta forma, o manejo de colostro é fundamental para a prevenção da $\mathrm{BRD}$, ao menos nas primeiras quatro semanas de vida. A meia vida dos anticorpos específicos contra o BoHV-1, BVDV, BPI3-V e BRSV é de 21, 23, trinta e
35 dias, respectivamente ${ }^{101}$. A duração dos anticorpos maternais em níveis protetores depende da quantidade de imunoglobulinas absorvidas e ingeridas pelo neonato, o que irá determinar a precocidade da doença no sistema de criação de bezerras. Além das particularidades etárias, a imunidade das bezerras ainda pode ser influenciada negativamente por dietas restritivas, manejo estressante e protocolos de vacinação inapropriados. Dentre as principais práticas estressantes destacam-se as descornas, o desaleitamento, ressocialização na formação de grupos após o desaleitamento e transporte.

Em relação ao ambiente, a incidência das broncopneumonias pode ser influenciada pela localização geográfica, estação do ano e pelas instalações ${ }^{5,102,103}$. A $\mathrm{BRD}$ é mais frequente no outono e inverno, quando comparados com o verão ${ }^{5}$. De acordo com pesquisa previamente publicada ${ }^{102}$, as bezerras criadas em grupos de seis a trinta animais, com alimentadores automáticos, apresentaram maiores chances de desenvolverem $\mathrm{BRD}$, quando comparadas com bezerras em gaiolas individuais (Odds ratio: 2,2 e IC95\%: 1,2-3,8). Pensando nisso foi desenvolvido o conceito de bezerreira ideal ("Ideal Wisconsin Calf Pen") para promover um ambiente saudável para a criação de bezerras, de acordo com os seguintes critérios: espaço e superfície de descanso com aproximadamente $3 \mathrm{~m}^{2}$ por animal, com a área limpa e seca, que ajude a isolar a bezerra do solo nos meses frios do ano. Deve-se ainda evitar baixas temperaturas do ar e variações climáticas. Os alojamentos individuais devem contemplar divisórias sólidas entre as gaiolas para evitar contato entre os animais. Lago e colaboradores $^{103}$ verificaram que bezerras criadas com divisórias sólidas apresentaram menor ocorrência de BRD. As paredes do alojamento devem ter pelo menos 1,2 $\mathrm{m}$ de altura para minimizar correntes de ar e limitar o contato focinho com focinho ${ }^{103}$.

Os principais agentes infecciosos primários envolvidos na fisiopatologia das broncopneumonias são Vírus Respiratório Sincicial Bovino (BRSV), 
Vírus da Parainfluenza Bovina (BPIV-3), Herpesvírus Bovino tipo 1 (BoHV-1), Vírus da Diarreia Viral Bovina (BVDV), Adenovírus Bovino A-D (BAdV-A-D) e Coronavírus $(\mathrm{BCoV})$. As bactérias são responsáveis pelas infecções secundárias, sendo as principais a Mannheimia haemolytica, Pasteurella multocida, Histophilus somnus e Mycoplasma bovis ${ }^{101}$. Infecções por vírus e bactérias causam as lesões patológicas características da $\mathrm{BRD}^{104}$.

Os vírus respiratórios penetram a mucosa do trato respiratório. O BRSV infecta o epitélio bronquial, leva à formação de células sinciciais e bronquiolite, sendo o quadro clínico caracterizado por febre, tosse, aumento da frequência respiratória e depressão. $\mathrm{O}$ BoHV-1 causa apoptose das células epiteliais, provoca febre, rinotraqueíte, tosse, conjuntivite, úlceras orais e infecção do trato reprodutivo com abortamentos. $\mathrm{O}$ BVDV é transmitido pelas secreções, e causa infecção persistente ou transitória, com múltiplos quadros clínicos, especialmente BRD e doença reprodutiva. Ambas as bactérias (Mannheimia haemolytica, Pasteurella multocida) compõem a microbiota do trato respiratório anterior do hospedeiro, e em condições de estresse e/ou infecção viral podem causar broncopneumonia. O Histophilus somnus é membro da microbiota dos tratos respiratório superior e reprodutivo, sendo responsável por meningoencefalite trombótica, doença respiratória, miocardite, polisinovite, otite média, mastite e doença do sistema reprodutivo. O Mycoplasma bovis causa mastite, otite média, artrite, broncopneumonia, febre, tosse, anorexia, descarga nasal, forma biofilmes para aumentar a sua sobrevida no ambiente e atua em sinergismo com os vírus respiratórios ${ }^{104}$.

O exame clínico do sistema respiratório contempla a avaliação dos movimentos respiratórios, que inclui a frequência respiratória, tipo respiratório, sendo normal o tipo costoabdominal, e ritmo, com relação inspiração:expiração de 1 a 1,2. Pode-se avaliar a laringe e faringe por inspeção externa e interna através de laringoscópio, e também realizar palpação da região. A traqueia pode ser inspecionada e palpada externamente, além de poder ser realizado lavado traqueal para realização de testes micológicos, bacteriológicos e sorológicos. Os pulmões e pleura são examinados pela observação dos movimentos respiratórios, percussão acústica, primeiramente horizontal, estabelecendo os limites posteriores caudais e posteriormente vertical, estabelecendo mudanças na ressonância pulmonar normal que deve ser clara, além da avaliação da sensibilidade, com o auxílio de um martelo pesado, e auscultação dos campos pulmonares ${ }^{105,106}$.

Os ruídos respiratórios normais são produzidos pelo turbilhonamento do ar nas ramificações do trato respiratório, sendo responsável pela gênese dos ruídos respiratórios traqueobrônquico e laringotraqueal, durante a inspiração e a expiração, e o ruído respiratório broncobronquiolar apenas durante a inspiração ${ }^{105}$. Os principais sintomas das broncopneumonias são inapetência, anorexia, dispneia, tosse, corrimento nasal e ocular, hipertermia, taquicardia, exacerbação e alteração dos ruídos respiratórios. Nas doenças pulmonares podem ser detectados ruídos anormais como crepitações, sibilos e roce pleural. As crepitações são ruídos semelhantes à uma explosão curta e descontinuada, produzida quando ocorre um desvio na passagem do ar nas vias respiratórias, devido à presença de secreção e exsudato ${ }^{105,106}$. O sibilo é um ruído de altura e tom constantes, formados pela aceleração da passagem de ar, nos casos de estreitamento das vias aéreas, ocorrendo com frequência nos casos de bronquite ${ }^{105}$. O roce pleural é um ruído de atrito entre o folheto parietal e visceral da pleura, produzido nos processos que levam inflamação e deposição de fibrina, gerando um som semelhante ao de esfregar de duas folhas de pape ${ }^{107}$.

A busca de um método para a triagem e detecção da BRD nas fazendas continua sendo um desafio, o que acarreta no tratamento tardio e com menores chances de cura. McGuirk ${ }^{27}$ desenvolveu o Calf Health Scoring Criteria (CHSC) para triagem da BRD, de forma que o método seja realizado ao redor de dois minutos. 
Neste escore é avaliada a temperatura retal, secreção nasal, secreção ocular, tosse com indução e posição de cabeça e orelhas, pontuados de zero a três, de acordo com a gravidade (Quadro 6). As bezerras com a soma total dos parâmetros $\geq 4$ são positivos para $\mathrm{DRB}$, com ponto de corte baseado em citologia do fluido broncoalveolar e validado por cultura, porém sem a publicação dos dados pela autora.

Love e colaboradores ${ }^{108}$ desenvolveram o escore BRD3 Scoring System (Bovine Respiratory Disease), baseado na presença ou ausência de hipertermia $\left(39,2^{\circ} \mathrm{C}\right)$, secreção nasal, secreção ocular, tosse espontânea, posição de cabeça e orelhas e qualidade da respiração. $\mathrm{Na}$ ausência e presença dos sinais a pontuação atribuída é zero ou dois, respectivamente, com exceção da presença de alterações na posição da cabeça e orelha (pontuação 5) e secreção nasal (pontuação 4). A soma das pontuações $\geq 5$ indica positividade para BRD. É importante ressaltar que ambos os escores respiratórios não foram validados para uso em países com clima subtropical ou tropical.

A avaliação pulmonar por meio da ultrassono-

Quadro 6. Escore para a detecção da Doença Respiratória Bovina, utilizando o sistema de escore adaptado de McGuirk²7.

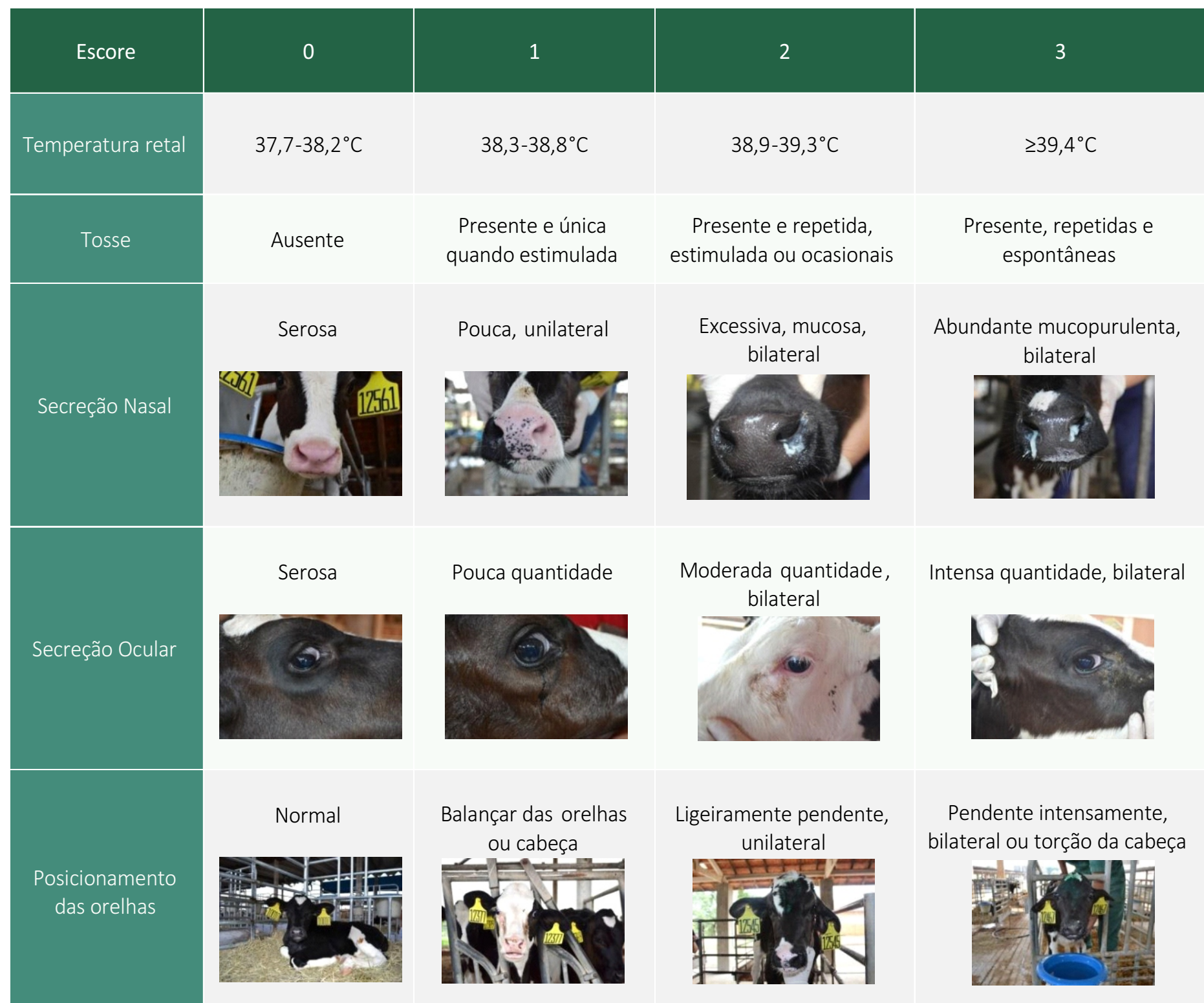



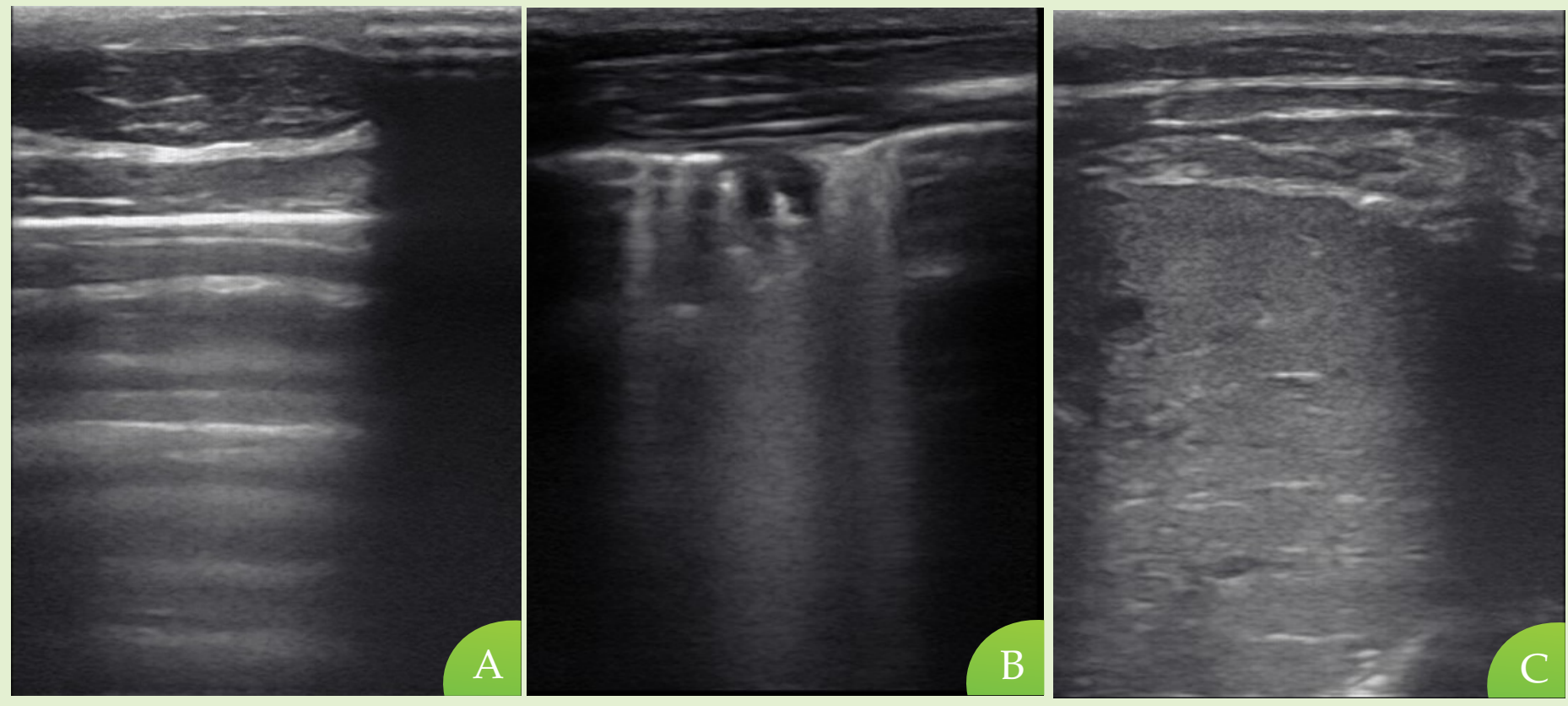

Figura 7. Imagens ultrassonográficas de pulmão normal e alterado. (A) Imagem do exame ultrassonográfico de pulmão normal, caracterizada pela presença de uma linha hiperecoica com reverberações; (B) Imagem apresentando pequena área de consolidação pulmonar e cauda de cometa; (C) Imagem apresentando uma estrutura hipoecoica homogênea similar ao fígado, correspondente a extensa área de consolidação pulmonar - Ultrassom M5Vet (Mindray Medical Brazil Limited) e transdutor linear, com frequência de 7,5 MHz.

grafia pode detectar e caracterizar efusão pleural, lesões pulmonares superficiais, consolidação, atelectasia e pneumotórax, e em alguns casos pode ser mais precisa que a radiografia ${ }^{109}$. A utilização do exame ultrassonográfico para detectar lesões pulmonares obteve sensibilidade de $94 \%$ e especificidade de $100 \%{ }^{110}$, enquanto que a radiografia apresentou sensibilidade de 94\% e especificidade de 50\%, comparando os exames com a detecção das lesões post mortem no pulmão ${ }^{111}$. A ultrassonografia possui maior facilidade de execução nas fazendas, pois pode ser feita em aparelhos portáteis, sem anestesia do animal e risco de exposição à radiação.

Para avaliação pulmonar com o uso de ultrassom em bovinos, a frequência e os transdutores variam de 3,5 a 7,5 MHz, em transdutores setoriais ${ }^{112}, 3,5$ a 13 $\mathrm{MHz}$ para os lineares ${ }^{113}$ e $5 \mathrm{MHz}$ nos convexos ${ }^{12}$. De acordo com Ollivett ${ }^{113}$, o uso de transdutores lineares permite a avaliação dos primeiros espaços intercostais e aumenta a sensibilidade do diagnóstico, pois a maior ocorrência de lesões é observada na porção cranial do lobo cranial direito. A técnica consiste na avaliação dos espaços intercostais, a partir do terceiro ao $11^{\circ}$ ou $12^{\circ}$ espaço $^{12,114}$, utilizando álcool ou gel para ultrassonografia, para o contato entre a pele e o transdutor ${ }^{113}$.

Agentes bacterianos e ocasionalmente agentes virais resultam em lesões nos lóbulos pulmonares, que alteram sua densidade, podendo modificar a imagem do exame ultrassonográfico, que é caracterizada como uma linha hiperecoica com reverberações (Figura 7A). Modificações estas que resultam na presença de artefatos de reverberação, denominados artefatos de "caudas de cometas" podendo ser originados por irregularidades da pleura ou do parênquima, acúmulo de líquido pleural ou presença de abscessos, podendo ser notados no exame como áreas bem delimitadas de bordas hiperecoicas, com conteúdo hipoecoico ou heterogêneo, e uma estrutura hipoecoica homogênea similar ao fíga- 
do, correspondente à consolidação pulmonar (Figura $7 \mathrm{~B}$ e C) $)^{110,115,116}$.

Ollivett \& Buczinski ${ }^{111}$ apresentaram um sistema de escore ultrassonográfico que é utilizado para caracterizar as imagens visualizadas no ultrassom de bezerros. A imagem que apresenta o pulmão como uma linha brilhante e hiperecoica, com um pulmão aerado e sem presença de consolidação é classificada como escore 0 . Presença de artefatos de cauda de cometa difusos, porém sem a presença de consolidação pulmonar é escore 1 . O escore 2 indica pneumonia lobular ou em áreas isoladas, essas pequenas lesões lobulares na maioria dos casos são virais e podem não requerer tratamento. $\mathrm{O}$ escore 3 indica a pneumonia lobar, afetando apenas um lobo com área de consolidação pulmonar. Quando dois lobos são afetados apresentando consolidação do parênquima, o escore atribuído é 4 . No escore 5 a consolidação pulmonar afeta 3 ou mais $\operatorname{lobos}^{111}$.

Andrade ${ }^{117}$, utilizando a ultrassonografia como padrão-ouro para a detecção de lesões pulmonares, constatou que a sensibilidade da auscultação foi de apenas $30 \%$.

A detecção do agente etiológico pela coleta de material para realização de exames complementares ou, até mesmo, necropsia é fundamental para a elaboração de protocolos terapêuticos e preventivos específicos ao rebanho alvo. Deve-se optar pela coleta de amostras clínicas provenientes de animais manifestando broncopneumonia aguda, ao invés dos casos crônicos, para evitar a detecção de agentes secundários ou terciários oportunistas. O método de coleta, meios de transporte, conservação das amostras e indicações dos testes laboratoriais para a detecção dos agentes virais e bacterianos causadores das broncopneumonias, estão indicados no Quadro 7.

O exame necroscópico deve ser realizado por equipe paramentada com EPIs (Equipamentos de Proteção Individual), em local isolado, com o solo previamente recoberto com lona, para evitar a contaminação ambiental e prevenir infecções em outros animais do rebanho. Deve-se realizar o procedimento post mortem

Quadro 7. Método de coleta, meios de transporte, conservação das amostras e indicações dos testes laboratoriais para a detecção dos agentes virais e bacterianos envolvidos na fisiopatologia das broncopneumonias em bovinos.

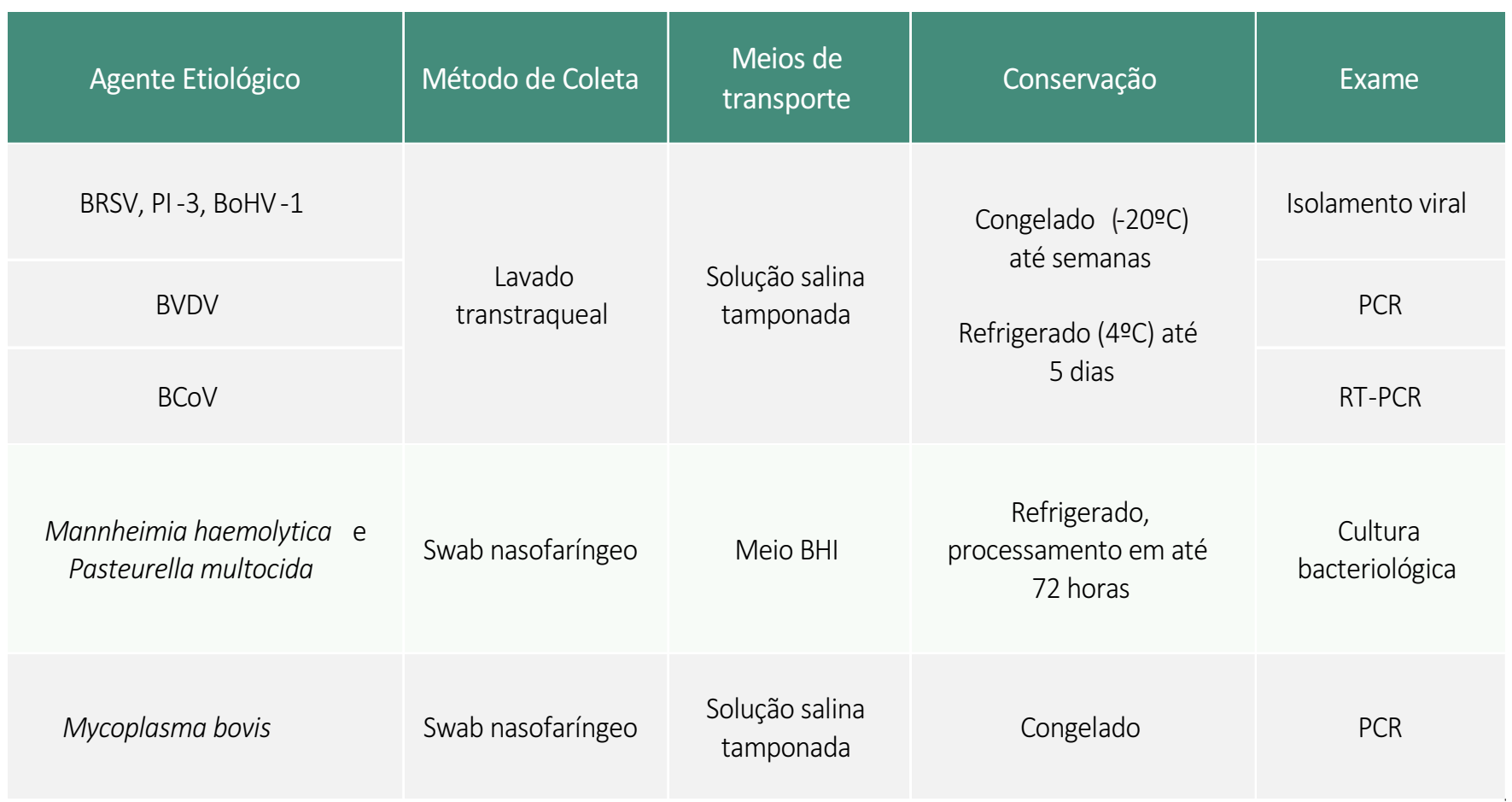

BHI: Brain heart infusion; PCR: Polymerase Chain Reaction; RT-PCR: Reverse transcriptase-Polymerase Chain Reaction. 
à sombra, para evitar maior deterioração do cadáver. Registrar as alterações macroscópicas por meio de fotografias, de acordo com a localização, tamanho, cor, forma, consistência, número, extensão, superfície, corte, conteúdo, distribuição e odor ${ }^{118}$. É importante que também sejam enviadas amostras dos tecidos em solução de formol a 10\% para um laboratório diagnóstico, para a realização de exame histopatológico. As amostras teciduais devem ser coletadas logo após a morte do animal, evitando alterações decorrentes da autólise tecidual pós-morte. Recomenda-se a coleta de fragmentos dos pulmões, linfonodos traqueais e mesentéricos, fragmentos de pele da orelha, do rim, baço e fígado. $\mathrm{O}$ acondicionamento dos órgãos deve ser realizado em frascos limpos e bem vedados. O transporte das amostras refrigeradas até o laboratório de microbiologia precisa ser em frasco limpo, dentro de isopor com gelo, de preferência reciclável. É importante que as amostras sejam identificadas com número do animal e o nome órgão coletado ${ }^{27,118}$.

O tratamento das broncopneumonias é baseado no uso de antimicrobianos e anti-inflamatórios. A escolha do antimicrobiano não deve ser feita de maneira aleatória, sendo importante levar em consideração os agentes infecciosos responsáveis pelo quadro clínico, histórico da propriedade e cronicidade da doença. A terapia com antimicrobianos de amplo espectro, preferencialmente pela via parenteral, deve ser iniciada mesmo antes da realização de exames microbiológicos para identificar o agente responsável. Os antimicrobianos mais comumente utilizados nas terapias da BRD são a oxitetraciclina, penicilina $G$ procaína e sulfa com trimetropima. Outras drogas também são extremamente eficazes como a tilmicosina, florfenicol e a tulatromicina. Apesar desta indicação inicial, é importante realizar a identificação dos agentes etiológicos e o teste de sensibilidade aos antimicrobianos (antibiograma), para a seleção do antimicrobiano adequado diante de resposta inadequada e casos clínicos futuros na mesma propriedade ${ }^{55}$. Uma recente meta-análise reportou que a tulatromicina, seguida por enrofloxacina e florfenicol, apresentaram respostas mais eficazes para o tratamento da $\mathrm{BRD}^{119}$.

A terapia com anti-inflamatórios deve ser combinada com a terapia antimicrobiana apropriada em casos graves de DRB. Uma resposta benéfica à terapia deve ser aparente dentro de 12 a 24 horas, caracterizada por um declínio mais rápido da temperatura retal e um retorno mais rápido à alimentação normal e ingestão de água ${ }^{120}$.

A prevenção da BRD pode ser feita pela investigação e eliminação dos fatores de risco, além de evitar estresse e falha na transferência de imunidade passiva. A antissepsia do umbigo parece contribuir para a redução da mortalidade e morbidade decorrentes das broncopneumonias em até $50 \%{ }^{7}$. Outras medidas preventivas incluem o uso de vacinas comerciais, pois diminuem a probabilidade de infecção ou reduzem a gravidade da doença. No entanto, programas eficazes de vacinas para bezerras jovens são complexos devido à natureza do sistema imunológico destes animais e da influência dos anticorpos maternais ${ }^{99}$. Para superar esse problema, é indicado o uso de vacinas intranasais, responsáveis por induzir resposta imune humoral e produção de IgA. Este anticorpo irá neutralizar agentes infecciosos na superfície da mucosa do trato respiratório, prevenindo assim a infecção, ao invés de apenas reduzir a gravidade da doença, como é esperado com a administração da vacina parenteral ${ }^{7,99}$.

\section{BIOSSEGURIDADE EM BEZERREIROS}

A biosseguridade pode ser definida como o conjunto de manejo ou medidas que gerencie o risco biológico, de modo a identificar o risco de doenças e prevenir a entrada e disseminação de agentes patogênicos dentro de um sistema de produção animal, uma vez que o risco de uma doença não pode ser totalmente eliminado, mas pode ser gerenciado por meio de medi- 
das de controle eficazes ${ }^{121}$.

A bovinocultura tem evoluído perceptivelmente para implementação das práticas de biosseguridade nos rebanhos, especialmente em algumas fases do ciclo de produção, devido à susceptibilidade aos agentes infecciosos decorrentes do status fisiológico e imunológico do hospedeiro. Dentro desta premissa, as vacas no período de transição e bezerras na fase de cria devem ser priorizadas no planejamento de um Programa de Biosseguridade. Apesar disto, um levantamento nacional realizado em 2020 demonstrou que apenas $32 \%$ (19/59) das fazendas entrevistadas adotam medidas de biosseguridade nos seus respectivos bezerrei$\operatorname{ros}^{96}$.

A implementação das medidas de biosseguridade nos primeiros sete dias de vida diminui os índices de morbidade no primeiro ano de vida dos animais, com possíveis benefícios econômicos, por reduzirem as perdas diretas e indiretas no sistema de produção ${ }^{122}$. A colostragem é um manejo considerado prioritário em um sistema de criação de bezerras, por transferir anticorpos específicos contra uma ampla diversidade de agentes infecciosos, o que garante o seu espectro de ação na neutralização de micro-organismos envolvidos nas diarreias neonatais, inflamações umbilicais, broncopneumonias e sepse.

As bezerras nascem agamaglobulinêmicas, devido a não transferência de anticorpos maternos ao feto, em virtude da placenta sinepteliocorial bovina. Além disso, neonatos possuem sistema imune adaptativo virgem e imunossuprimido, em função da interação entre os hormônios e citocinas presentes no ambiente materno-fetal. Apesar de apresentarem todos os componentes essenciais, a montagem da resposta imune pós-natal inicialmente é lenta e de baixa intensidade, devido à imaturidade funcional das células imunes. Sendo assim, a transferência de imunidade passiva é essencial para a proteção das bezerras contra as doenças nessa fase crítica da vida ${ }^{94,99}$.

Um programa de manejo de colostro bem- sucedido é baseado no princípio dos 3Q's: quantidade, qualidade e quão rápido. $\mathrm{O}$ padrão ouro de qualidade desse colostro está intrinsicamente ligado aos níveis de $\mathrm{IgG}$, que devem ser $\geqslant 50 \mathrm{mg} / \mathrm{mL}$; no índice de qualidade firmado no refratômetro tipo Brix $\geqslant 25 \%$; níveis de $<50.000$ UFC/mL (Unidades Formadoras de Colônias/mL) para Contagem Padrão em Placas (CPP) e $<5.000 \mathrm{UFC} / \mathrm{mL}$ para contagem de coliformes. A quantidade e rapidez deve seguir obrigatoriamente, $10 \%$ do peso corporal ao nascimento (PCN) de colostro de alta qualidade ( $\geq 25 \%$ de Brix) na primeira refeição, por mamadeira ou sonda, em até duas horas de vida. Fornecer mais 5\% do PCN, na segunda mamada, sem forçar a ingestão, em até oito horas de vida ${ }^{96,123 .}$

A falha na transferência de imunidade passiva (FTIP) pode ser monitorada pela mensuração da proteína total ou \% de sólidos totais do soro sanguíneo, utilizando-se refratômetro de Brix (\%) ou de proteína total ( 0 a $12 \mathrm{~g} / \mathrm{dL})$. O ideal é avaliar as bezerras entre 24 e 48 horas de vida. Os valores de leitura obtidos como pontos de corte são: > 5,5 g/dL (escala de 0 a $12 \mathrm{~g} / \mathrm{dL}$ ) para proteína total sérica e $>8,4 \%$ (escala de 0 a $30 \%$ ) para o refratômetro de Brix ${ }^{123}$.

As estratégias utilizadas para a prevenção das doenças nos rebanhos estão direcionadas às vias de transmissão dos principais agentes infecciosos. A via aerógena é considerada uma rota de infecção muito rápida, sendo a principal via de transmissão das broncopneumonias. Os agentes infecciosos podem se estabilizar em gotículas/poeira e pelo ar. Deve-se controlar a velocidade e qualidade do ar nos bezerreiros, podendo ser corrigida com o uso de ventiladores e quebraventos. É possível mensurar a velocidade do ar com aparelho digital anemômetro portátil, sendo a faixa média preconizada de $0,50 \mathrm{~m} / \mathrm{s}^{124}$. Além disso, a qualidade microbiológica do ar deve ser investigada para detecção de bactérias, leveduras e fungos. As análises podem ser realizadas por placas microbiológicas aleatórias, alocadas nas gaiolas, e em casos de bezerreiros coletivos, a amostragem pode ser realizada em local 
com aproximadamente dois metros de distância em relação ao alimentador. É recomendado que as placas fiquem expostas ao menos quinze minutos em contato com o $\operatorname{ar}^{116}$.

A umidade relativa do ar deve ser mantida entre 50 e 75\%, para minimizar a sua condensação, além da limpeza de dejetos para diminuição do odor amoniacal $^{124}$. Outras medidas contemplam a disponibilização de sombra, com tela de tecido de sombreamento de $80 \%$, com uma faixa suspensa com pelo menos 2,1 metros de altura, em sistemas de criação do tipo argentino ou tropical; orientar os abrigos no sentido norte-sul para maximizar a exposição ao sol e desinfecção nas áreas de descanso, garantindo disponibilidade de sombra ${ }^{96}$.

As contaminações por contato direto ocorrem pela proximidade de animais, focinhos, lambeduras, sucções e mamadas cruzadas. Evitar gaiolas com aberturas laterais, que possibilitem o contato direto das bezerras com saliva, feridas e secreções. A proximidade entre os animais aumenta o risco de doenças (Odds ratio: 4,6 e IC 95\%: 1,6-20,1). O controle da densidade populacional de animais no local deve sempre ser monitorado, respeitar a proximidade entre os animais (mínimo 1,5 a 2,0 metros), bezerras alojadas em baias ou abrigos individuais devem ter aproximadamente 2,4 $\mathrm{x}$ $2,0 \mathrm{~m}^{2}$, enquanto bezerras alojadas em grupos devem ter um mínimo de $8,5 \mathrm{~m}^{2} /$ animal, a distância mínima preconizada é 3,3 $\mathrm{m}^{2}$ metros de espaço de descanso por animal $1^{96,125}$.

Há evidências de que o contato direto entre as bezerras jovens aumenta o risco de adquirir Criptosporidiose $^{126}$. O tamanho ideal para as gaiolas em que os animais permanecerão até os trinta dias de idade, deve seguir as medidas de no mínimo 1,0 m de largura por $1,5 \mathrm{~m}$ de comprimento e $1,2 \mathrm{~m}$ de altura, acima de trinta dias de idade, seguir as medidas de no mínimo $1,2 \mathrm{~m}$ de largura por 1,8 $\mathrm{m}$ de comprimento e 1,3 $\mathrm{m}$ de altu$\mathrm{ra}^{96}$.

A transmissão via oral-fecal possibilita as bezerras com diarreia a disseminarem altas concentrações de agentes patogênicos no ambiente, muitas vezes a contaminação ocorre por meio do consumo de leite, água e outros alimentos contaminados. A prevenção pode ser realizada com manejo corretos de dejetos (fezes e urina), isolamento dos animais doentes, limpeza correta dos equipamentos utilizados, ambiente seco, limpo e desinfetado, garantir água e alimentos com adequada qualidade microbiológica, para evitar o contágio com agentes contaminantes como Salmonella spp, Vibrio cholera, Leptospira spp., Escherichia coli e Pseudomonas spp. ${ }^{127}$.

A qualidade da água pode variar em relação à sua utilidade, os valores máximos aceitáveis nas áreas de produção são de $2 \mathrm{mg} / \mathrm{L}$ para cloro residual livre, $\mathrm{pH}$ entre 6,0 a 9,5, turbidez 5 uts (unidade de turbidez), coliformes totais ausentes em $100 \mathrm{~mL}$, Escherichia coli ausente em 100 mL; concentração de sódio de 100 ppm (partes por milhão) ${ }^{128}$. Usualmente, uma filtração seguida de uma cloração resolve o problema de $90 \%$ das águas disponíveis. A cloração é uma das formas mais eficazes de desinfecção da água e inibição da proliferação dos principais agentes infecciosos. Para a eliminação dos microrganismos na água por cloração, basta a adição de hipoclorito de sódio até que os traços de cloro livre concentrem os padrões de normalidade ${ }^{129}$.

O Processo de Limpeza e Desinfecção (PLD) é um dos pontos chave que deve ser contemplado em um programa de biosseguridade, pois minimiza a transmissão de agentes infecciosos via fômites, tais como mamadeiras, bicos, baldes, sondas e outros equipamentos compartilhados entre as bezerras, assim como as vias aerógena e oral, em ambientes contaminados ( $\mathrm{Fi}^{-}$ gura 8).

Um levantamento feito pela Alta Cria em $2020^{3}$, constatou que os cinco produtos mais utilizados nos protocolos de limpeza e higienização dos utensílios foram à base de detergente neutro (74\%), detergente alcalino (23\%), dióxido de cloro (44\%), cloreto de alquil dimetil benzil amônio (34\%) e hipoclorito de sódio 

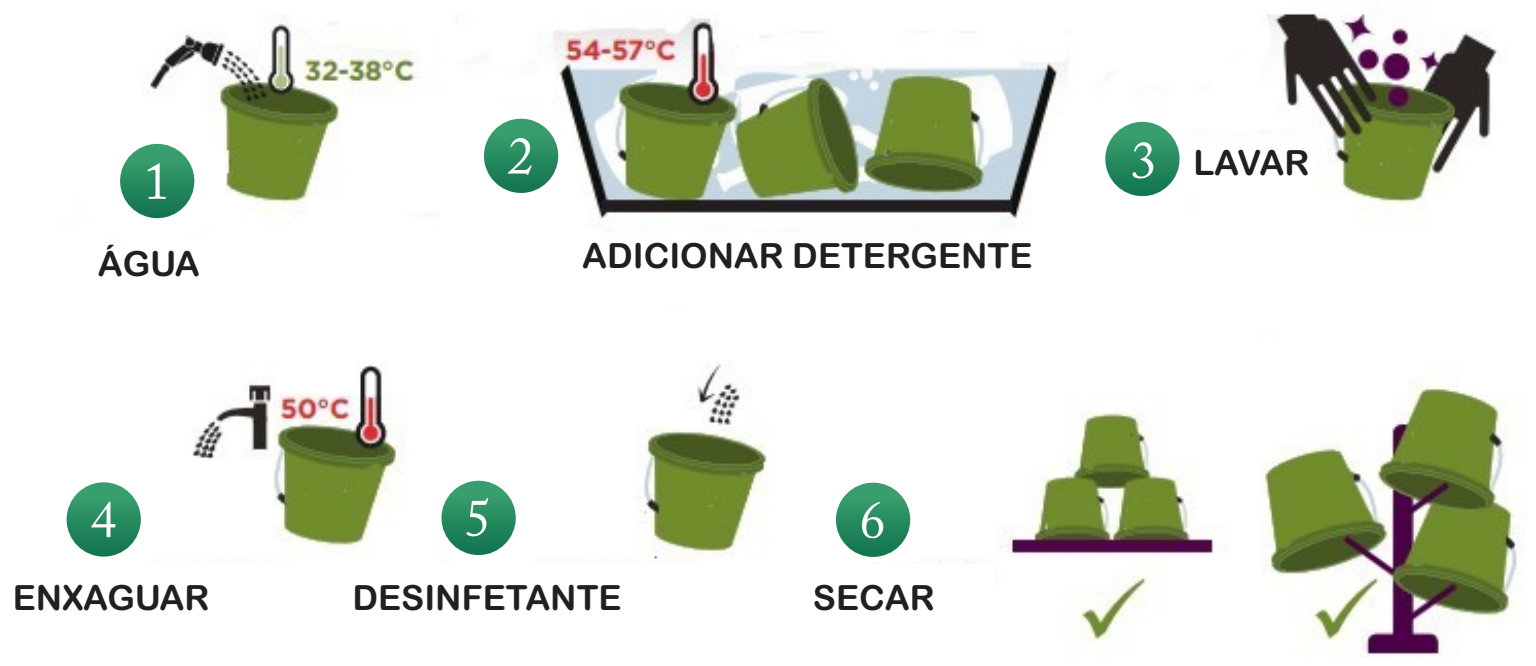

Figura 8. Esquema demonstrando as etapas para o processo de lavagem e desinfecção dos utensílios utilizados para o aleitamento das bezerras.

(17\%). Em relação às instalações das bezerras, os produtos mais utilizados foram detergentes neutro (19\%), cal (óxido de cálcio, 52\%), dióxido de cloro (50\%), vassoura de fogo (21\%) e composto de sulfato hidrogenado de potássio, dodecil benzeno sulfonato de sódio, monopersulfato de potássio, sulfato de potássio e ácido sulfâmico (21\%). O vazio sanitário de dez a quatorze dias também diminui o risco de doença, quando comparados bezerreiros que adotam vazio de zero a nove dias entre a saída e entrada de novos animais (Odds ratio: 0,42 e IC95\%: $0,21-0,87)^{130}$. O vazio sanitário perde o sentido, a depender da adoção do PLD e espectro de ação do desinfetante.

Os princípios ativos dos desinfetantes variam quanto ao espectro de ação antimicrobiano, podendo combater microrganismos de extrema preocupação, como Mycoplasma bovis, bactérias gram-positivas e negativas, especialmente Pseudomonas spp., vírus, protozoários (Cryptosporidium spp.), esporos fúngicos entre outros. Dentre as composições, em termos de criação de bezerras para a diarreia neonatal, os principais agentes causadores são Escherichia coli, Salmonella spp., Rotavirus, Coronavirus, Cryptosporidium spp. ${ }^{131}$. Para estes agentes bacterianos, as opções de princípios ativos com potencial de eliminação são os aldeídos (glutaraldeídos, formaldeídos), hipocloritos (de sódio, de cálcio), para o Cryptosporidium spp. tem se direcionado para o desinfetante a base de dióxido de cloro, e para os vírus, a mistura de compostos de sulfato hidrogenado de potássio, dodecil benzeno sulfonato de sódio, monopersulfato de potássio, sulfato de potássio e ácido sulfâmico.

Outras doenças comuns nessa fase são as respiratórias, caracterizadas pelos vírus da Diarreia Viral Bovina (BVDV), Herpesvírus Bovino Tipo 1 (BoHV1), Parainfluenza Bovino Tipo 3 (PI3), Vírus Respiratório Sincicial Bovino (BRSV) e por bactérias como Mannheimia haemolytica, Pasteurella multocida, Histopbilus somni, e em casos crônicos, a infecção pode evoluir para a instalação de bactérias oportunistas como Trueperella pyogenes, Fusobacterium spp., Bacteriodes spp. e Mycoplama bovis ${ }^{132}$. Para as bactérias, os desinfetantes à base de aldeídos (glutaraldeídos, formaldeídos), alcalis (hidróxido de sódio, hidróxido de amônia), hipocloritos (de sódio, de cálcio), dióxido de cloro e peróxidos são os mais indicados (Quadro 8), para os vírus, o desinfetante mais eficaz é uma mistura de compostos de sulfato hidrogenado de potássio, dodecil benzeno sulfonato de sódio, monopersulfato de potássio, sulfato de potássio e ácido sulfâmico. 
Além da escolha do espectro de ação do desinfetante, de acordo com o desafio, é de suma importância seguir as instruções do fabricante quanto a diluição, tempo de ação recomendada, necessidade de enxágue, utilização de EPIs durante o manuseio e remoção prévia da matéria orgânica ${ }^{133}$.

Por fim, o sucesso de um programa de biosseguridade pode ser prejudicado pela baixa adesão dos pecuaristas em seguir as recomendações fornecidas, seja pela influência da percepção de risco do produtor quanto a utilidade e importância, não observação de medidas eficientes, falta de conscientização dos colaboradores e mão de obra ${ }^{134}$. Dessa forma, é fundamental ressaltar a importância da comunicação do risco biológico a todos colaboradores e gerenciamento das equipes de forma simples, eficiente e prática. Assim, a conscientização e a valorização de cada medida serão indispensáveis para obtenção de bezerras saudáveis e produtivas.

Quadro 8. Espectro de ação dos principais princípios ativos de desinfetantes.

\begin{tabular}{|c|c|c|c|c|c|c|c|c|c|}
\hline Agentes & Ácidos ${ }^{1}$ & Alcoois $^{2}$ & Aldeídos $^{3}$ & Álcalis ${ }^{4}$ & Biguanidinas 5 & Halógenos ${ }^{6}$ & Peroxígenos 7 & Fenóis $^{8}$ & $\begin{array}{c}\text { Amônia } \\
\text { quaternária9 }\end{array}$ \\
\hline Mycoplasma & + & ++ & ++ & ++ & ++ & ++ & ++ & ++ & + \\
\hline Bact. gram+ & + & ++ & ++ & + & ++ & + & + & ++ & ++ \\
\hline Bact. gram- & + & ++ & ++ & + & ++ & + & + & ++ & + \\
\hline Pseudomonas & + & ++ & ++ & + & \pm & + & + & ++ & - \\
\hline Ricktesias & \pm & + & + & + & \pm & + & + & + & \pm \\
\hline $\begin{array}{c}\text { Vírus } \\
\text { envelopado }\end{array}$ & + & + & ++ & + & \pm & + & + & \pm & \pm \\
\hline Clamídias & \pm & \pm & + & + & \pm & + & + & \pm & - \\
\hline $\begin{array}{c}\text { Vírus não } \\
\text { envelopado }\end{array}$ & - & - & + & \pm & - & + & \pm & - & - \\
\hline $\begin{array}{l}\text { Esporos } \\
\text { fúngicos }\end{array}$ & \pm & \pm & + & + & \pm & + & \pm & + & \pm \\
\hline Piconavírus & + & $\mathrm{N}$ & + & + & $\mathrm{N}$ & $\mathrm{N}$ & + & $\mathrm{N}$ & $\mathrm{N}$ \\
\hline Parvovírus & $\mathrm{N}$ & $\mathrm{N}$ & + & $\mathrm{N}$ & $\mathrm{N}$ & + & \pm & $\mathrm{N}$ & - \\
\hline $\begin{array}{l}\text { Bact. Ácido } \\
\text { fast }\end{array}$ & - & + & + & + & - & + & \pm & \pm & - \\
\hline $\begin{array}{c}\text { Esporos } \\
\text { bacterianos }\end{array}$ & \pm & - & + & \pm & - & + & + & - & - \\
\hline Coccidios & - & - & - & + & - & - & - & + & - \\
\hline Príons & - & - & - & - & - & - & - & - & - \\
\hline
\end{tabular}

Legenda: ${ }^{1}$ ácido acético, ácido cítrico; ${ }^{2}$ etanol, isopropanol; ${ }^{3}$ glutaraldeído, formaldeído; hidróxido de sódio, de amônia; clorexidine; hipoclorito de sódio,iodo; monopersulfato de potássio, peróxido de hidrogênio. ++ altamente efetivo; + efetivo; \pm atividade limitada; - não efetivo; $\mathrm{N}$ sem informação. $\mathrm{CFSPG}^{133}$, adaptada por Gomes et al.(2021). 


\section{CONSIDERAÇÕES FINAIS}

O nascimento de bezerras é marcado por uma série de mudanças e adaptações fisiológicas ao ambiente extrauterino, às quais podem ser complicadas por distocias e adaptação neonatal inadequadas, predispondo os neonatos à um efeito em cascata que se inicia com a asfixia neonatal, falha na transferência de imunidade passiva, diarreias, onfalopatias e broncopneumonias. O gerenciamento sanitário das doenças no sistema de criação de bezerras é complexo e exige conhecimento e treinamento técnico e especializado. $\mathrm{O}$ controle epidemiológico das enfermidades é dependente da detecção precoce, identificação dos agentes etiológicos, protocolos de vacinação e a implementação das práticas de biosseguridade.

\section{AGRADECIMENTOS}

À Fundação de Amparo à Pesquisa de São Paulo (FAPESP), pela concessão dos auxílios à pesquisa processos no 2010/15865-9, 2012/02129-8, 2013/06152-7 e 2016/16748-2. Ao Cnpq pela concessão dos auxílios à pesquisa Processo n ${ }^{\circ}$ 249516/2013-6. Ás empresas Bayer Saúde Animal, MSD Saúde Animal, Valleé e Virbac, pelo financiamento de projetos de pesquisa. Aos produtores que apoiam a pesquisa científica e permitem o uso dos animais nos estudos desenvolvidos pela equipe GeCria, especialmente fazenda Colorado e fazenda Agrindus.

\section{REFERÊNCIAS}

1. HEINRICHS, A.J.; HEINRICHS, B.S. A prospective study of calf factors affecting firstlactation and lifetime milk production and age of cows when removed from the herd. Journal of Dairy Science, v.94,n.1, p.336-341,2011.

2. USDA. 2018. Dairy 2014, Health and Management Practices on U.S.Dairy Operations, 2014.

3. AZEVEDO, R.A. et al. Uberaba, Minas Gerais, $1^{\text {a }}$ Ed. 2020.108p.

4. WINDEYER, M.C. et al. Factors associated with morbidity, mortality, and growth of dairy heifer calves up to 3 months of age. Preventive Veterinary Medicine, v.113, n.2, p.231-40,2014.

5. SVENSSON, C. et al. Morbidity in Swedish dairy calves from birth to 90 days of age and individual calflevel risk factors for infectious diseases. Preventive Veterinary Medicine,v.58, n.3-4,p.179-197,2003.

6. NG, T.F.F. et al. A metagenomics and case-control study to identify viruses associated with bovine respiratory disease. Journal of Virology, v.89, n.10, p.53405349,2015 .

7. GORDEN, P.J.; PLUMMER, P. Control, management, and prevention of bovine respiratory disease in dairy calves and cows. Veterinary Clinics of North America: Food Animal Practice, v.26, n.2, p.243-259, 2010.

8. VIRTALA, A.M.K. et al. The effect of calfhood diseases on growth of female dairy calves during the first 3 months of life in New York State. Journal of Dairy Science, v.79, n.6, p.1040-1049,1996.

9. STUDDS, M.J. et al. Short communication: the effect of diarrhea and navel inflammation on the lying behavior of veal calves. Journal of Dairy Science, v.101, n.12,p.11251-11255,2018.

10. AGHAKESHMIRI, F. et al. Effects of neonatal diarrhea and other conditions on subsequent productive and reproductive performance of heifer calves. Veterinary Research Communications, v.41, n.2, p.107112,2017. 
11. STANTON, A.L. et al. The effect of respiratory disease and a preventative antibiotic treatment on growth, survival, age at first calving, and milk production of dairy heifers. Journal of Dairy Science, v.95, n.9, p.4950-4960,2012.

12.ADAMS, E.A.; BUCZINSKI, S. Short communication: ultrasonographic assessment of lung consolidation postweaning and survival to the first lactation in dairy heifers. Journal of Dairy Science, v.99, n.2, p.1465$1470,2016$.

13. BENESI, F.J. Síndrome asfixia neonatal nos bezerros. Importância e avaliação crítica. Arquivos da Escola de Medicina Veterinária da Universidade Federal da Babia,v.16,n.1, p.38-48,1993.

14. UYSTEPRUYST, C.H. et al. Effect of three resuscitation procedures on respiratory and metabolic adaptation to extra uterine life in newborn calves. Veterinary Journal,v.163, n.1,p.30-44,2002.

15. YASUOKA, M.M. et al. Transient pulmonary artery hypertension in Holstein neonate calves. Animals,v.10, n.12,p.2277,2020.

16. BIRGEL JUNIOR, E.H. et al. Distúrbios clínicos observados nos primeiros 30 dias de vida de bezerros clonados da raça Nelore. Acta Scientiae Veterinariae, v.39, p.243-252,2011.

17. BLEUL, U. Respiratory distress syndrome in calves. Veterinary Clinics of North America: Food Animal Practice,v.25, n.1,p.179-193,2009.

18. SANCHEZ-SALCEDO, J. et al. Therapeutics of neonatal asphyxia in production animals: a review. VeterinárníMedicína,v.64,n.5,p.191-203,2019.

19. WOOD, C.E. Control of parturition in ruminants. Journal of Reproduction and Fertility, v.54, p.115-126, 1999.
20. BLEUL, U. al. Blood gas and acid-base analysis of arterial blood in 57 newborn calves. Veterinary Record, v.161,n.20, p.688-691,2007.

21. APGAR, V.A. Proposal for a new method of evaluation of the newborn infant. Anesthesia E Analgesia, v.120,n.5,p.1056-1059,2015.

22. BORN, E. Untersuchungen über den einfluss der schnittentbindung auf die vitalität neugeborener kälber. 1981. 47f. Tese (Doutorado) - Tierärztliche Hochschule, Hannover, Germany.

23. SORGE, U. et al. Neonatal blood lactate concentration and calf morbidity. Veterinary Record, v.164, n.17,p.533-534,2009.

24. GOUVÊA, L.V.Análise hemogasométrica arterial e venosa de ovinos submetidos à transposição carotídea e indução de desequilíbrios ácido básicos. 2009. 49 f. Dissertação (Mestrado em Saúde Animal) Universidade Federal de Brasília, Brasília.

25. MURRAY, C.F. et al. The effect of dystocia on physiological and behavioral characteristics related to vitality and passive transfer of immunoglobulins in newborn Holstein calves. Canadian Journal of Veterinary Research,v.79, n.2,p.109-119,2015.

26. BLEUL, U. et al. Comparison of sodium bicarbonate and carbicarb for the treatment of metabolic acidosis in newborn calves. Veterinary Record, v.156, n.7, p.202-206,2005.

27. McGUIRK, S.M. Disease management of dairy calves and heifers. Veterinary Clinics of North America: Food Animal Practice, v.24,p.139-153,2008

28. BLEUL, U. et al. Respiratory and cardiovascular effects of doxapram and theophylline for the treatment of asphyxia in neonatal calves. Theriogenology, v.73, n.5, p.612-619,2010. 
29. BLEUL, U.T. et al. Effect of intranasal oxygen administration on blood gas variables and outcome in neonatal calves with respiratory distress syndrome: 20 cases (2004-2006). Journal of the American Veterinary MedicalAssociation, v.233, n.2,p.289-293,2008.

30. BUCZINSKI, S. et al. Mechanical ventilation of a cloned calf in respiratory failure. The Journal of Veterinary Emergency and Critical Care, v.17, n.2, p.179-183, 2007.

31.PALMER,J.E. Ventilatory support of the critically ill foal. Veterinary Clinics of North America: Food Animal Practice,v.21,n.2,p.457-486, 2005.

32. DONNELLY, C.G. et al. Respiratory support for pharmacologically induced hypoxia in neonatal calves. Veterinary Medicine International,v.2016, p.1-8, 2016.

33. BRIGANTI, A. et al. Continuous positive airway pressure administered via face mask in tranquilized dogs. The Journal of Veterinary Emergency and Critical Care,v.20, n.5, p.503-508, 2010.

34. HILL, J.R. et al. Clinical and pathologic features of cloned transgenic calves and fetuses (13 case studies). Theriogenology, v.51, n.8, p.1451-1465, 1999.

35. WATSON, E. et al. Ultrasonography of the umbilical structures in clinically normal calves. American Journal of Veterinary Research,v.55, n.6, p.773-80, 1994.

36. FIGUEIRÊDO, L.J.C. Onfalopatias de bezerros. Salvador:EDUFBA, 1999.p.31-34.

37. DONOVAN, G.A. et al. Associations between passive immunity and morbidity and mortality in dairy heifers in Florida, USA. Preventive Veterinary Medicine,v.34,n.1,p.31-46,1998.

38. RENGIFO, S.A. et al. Isolamento de agentes microbianos a partir de amostras de sangue e umbigo de bezerros mestiços neonatos. Brazilian Journal Veter- inary Research Animal Science, v.43, n.4, p.442-447, 2006.

39. REIS, G.A. Identificação e correlação dos agentes microbianos isolados a partir da secreção do umbigo e de amostras de sangue de bezerros com onfalite. 2017. 115f. Dissertação (Mestrado) - Faculdade de Medicina Veterinária e Zootecnia, Universidade de São Paulo, São Paulo.

40. FORDYCE, A.L. et al. Short communication: the effect of novel antiseptic compounds on umbilical cord healing and incidence of infection in dairy calves. Journal of Dairy Science, v.101,n.6,p.5444-5448,2018.

41. CONSTABLE, P. et al. (11 ed). Veterinary Medicine: A textbook of the diseases of cattle, horses, sheep, pigs and goats. Saunders, 2017.v.2,p.1830-1903.

42. BAIRD, A.N. Umbilical surgery in calves. Veterinary Clinics of North America: Food Animal Practice, v.24, n.3, p.467-477, 2008.

43. HOPKER, A. Umbilical swellings in calves: a continuing challenge. Veterinary Record, v.174, n.9, p.219220,2014

44. SHECAIRA, C.L. et al. Using thermography as a diagnostic tool for omphalitis on newborn calves. Journal of Thermal Biology,v.71,p.209-211,2018.

45. MULON, P.Y.; DESROCHERS, A. Surgical abdomen of the calf. Veterinary Clinics of North America: Food Animal Practice, v.21,n.1, p.101-132, 2005.

46. SEINO, C.H. et al. Avaliação ultrassonográfica de componentes umbilicais inflamados em bezerros da raça Holandesa com até 30 dias de vida. Pesquisa Veterinária Brasileira,v.36, n.6, p.492-502,2016.

47. KILIÇ, N. et al. Surgical correction of umbilical disease in calves: a retrospective study of 95 cases. Van Veterinary Journal,v.16,n.2,p.35-38,2005. 
48. STEERFORTH, D.D; WINDEN, S.V. Development of clinical sign-based scoring system for assessment of omphalitis in neonatal calves. Veterinay Record,v.182,n.19,p.549,2018.

49. REIS, A.S.B. et al. Onfalopatias em bezerros de rebanhos leiteiros no nordeste do Estado do Pará. Ciência Animal Brasileira, supl.1, Anais do VIII Congresso Brasileiro de Buiatria,p.20-34,2009.

50. BRISVILLE, A.C. et al. Neonatal morbidity and mortality of 31 calves derived from somatic cloning. Journal of Veterinary Internal Medicine, v.27, n.5, p.1218-1227,20013.

51. BOMBARDELLI, J.A. et al. Aspectos ultrassonográficos dos componentes umbilicais de bezerros da raça Holandesa durante o processo de involução fisiológica. Arquivos Brasileiro de Medicina Veterinária e Zootecnia, v.70, n.2, p.382-390,2018.

52. STURION, T.T. et al. Avaliação ultrassonográfica da involução das estruturas umbilicais extra e intracavitárias em bezerros sadios da raça Nelore concebidos naturalmente e produtos de fertilização in vitro. Pesquisa Veterinária Brasileira, v.33, n.8, p.10211032,2013.

53. GUERRI, G. et al. Ultrasonographic evaluation of umbilical structures in Holstein calves: a comparison between healthy calves and calves affected by umbilical disorders. Journal of Dairy Science, v.103, n.3, p.25782590,2020 .

54. GANGA N.S. et al. Navel ill in new born calves and its successful treatment. Veterinay World, v.4, n.7, p.326-327,2011.

55. CONSTABLE, P. et al. Diseases of respiratory system.In: CONSTABLE, P. et al. ed. Veterinary Medicine: A Textbook of the Diseases of Cattle, Horses, Sheep, Pigs and Goats. 11th ed. Saunders; 2017:845-
1090.

56. SILVA, L.A.F. et al. Tratamento de hérnia umbilical em bovinos. Ceres, v.59, n.1, p.39-47, 2012.

57. SOUZA FARIA, A.L.B. et al. Application of phototherapy for the healing of the navels of neonatal dairy calves. Lasers in Medical Science, v.32, n.7, p.1579$1586,2017$.

58. GROVER, W.M.; GODDEN, S. Efficacy of a new navel dip to prevent umbilical infection in dairy calves. The Bovine Practitioner, v.45, n.1, p.70-77,2011.

59. NDIKUWERA, J.; WINSTANLEY, E.W. The toxicity of povidone-iodine on fibroblasts. Irish Veterinary Journal,v.43,p.15-27,1990.

60. MADIGAN, J.E.; LAVAN, R. Umbilical disorders: new aspects of pathogenesis and preliminar considerations of methods of umbilical cord treatment regimens. Proceedings of the 14th Bain-Fallon Memorial Lectures,v.14, p.237-41,1992.

61. SINHA, A. et al. Chlorhexidine skin or cord care for prevention of mortality and infections in neonates. Cochrane Reviews, v.5,n.3,p.1-59,2015.

62. ROBINSON, A.L. et al. Short communication: the effect of 4 antiseptic compounds on umbilical cord healing and infection rates in the first 24 hours in dairy calves from a commercial herd. Journal of Dairy Science, v.98, n.8, p.5726-5728, 2015.

63. NAGY, D.W. Resuscitation and critical care of neonatal calves. Veterinary Clinics of North America: Food Animal Practice, v.25,n.1,p.1-11,2009.

64. FECTEAU, M.E. et al. Neonatal care of high-risk cloned and transgenic calves. Veterinary Clinics of North America: Food Animal Practice, v.21, n.3, p.637-653, 2005. 
65. CARVALHO, J.G. et al. Estudo longitudinal da infecção por enteropatógenos em bezerros neonatos, com diarreia, sob diferentes estratégias de aleitamento. Pesquisa Veterinária Brasileira, v.34, n.6, p.529-553, 2014.

66. HOLSCHBACH, C.L.; PEEK, S.F. Salmonella in dairy cattle. Veterinary Clinics of North America: Food Animal Practice,v.34,n.1,p.133-154,2018.

67. COURA, F.M. et al. Longitudinal study of Salmonella spp., diarrheagenic Escherichia coli, Rotavirus, and Coronavirus isolated from healthy and diarrheic calves in a Brazilian dairy herd. Tropical Animal Health and Production,v.47,n.1,p.3-11,2015.

68. ROCHA, T.G. et al. Longitudinal study of bovine rotavirus group $\mathrm{A}$ in newborn calves from vaccinated and unvaccinated dairy herds. Tropical Animal Health and Production, v.49, n.4,p.783-790, 2017.

69. FOSTER, D.M.; SMITH, G.W.Pathophysiology of diarrhea in calves. Veterinary Clinics of North America: Food Animal Practice, v.25, n.1, p.13-36, 2009.

70. ALFIERI, A.A. et al. Dairy calf rearing unit and infectious diseases: diarrhea outbreak by bovine coronavirus as a model for the dispersion of pathogenic microorganisms. Tropical Animal Health and Production,v.50, n.8, p.1937-1940,2018.

71. MARTIN, C.C. et al. Influence of early use of antimicrobial on the health and performance of Holstein calves in the first month of life. Pesquisa Veterinária Brasileira,v.40,n.1,p.17-28,2020.

72. GOMEZ, D.E.; WEESE, J.S. Viral enteritis in calves. Canadian Journal of Veterinary Research, v.58, n.12,p.1267,2017.

73. CHO, Y.I.; YOON, K.J. An overview of calf diarrhea-infectious etiology, diagnosis, and intervention.
Journal of Veterinary Science, v.15, n.1,p.1-17,2014.

74. FOSTER, J.C. et al. Effect of Lactobacillus and Bifidobacterium on Cryptosporidium parvum oocyst viability. Food Microbiology, v.20, n.3, p.351-357,2003.

75. DUREL, L.et al. Immune response of mature cows subjected to annual booster vaccination against neonatal calf diarrhoea with two different commercial vaccines: A non-inferiority study. Livestock Science, v.204, p.52-58,2017.

76. NGELEKA, M. et al. Frequency of Escherichia coli virotypes in calf diarrhea and intestinal morphologic changes associated with these virotypes or other diarrheagenic pathogens. Journal of Veterinary Diagnostic Investigation, v.31, n.4, p.611-615, 2019.

77. BERCHTOLD, J. Treatment of calf diarrhea: intravenous fluid therapy. Veterinary Clinics of North America: Food Animal Practice, v.25, n.1, p.73-99, 2009.

78. CONSTABLE, P.D. Comparison of two electrolyte solutions for the treatment of dehydrated calves with experimentally-induced diarrhea. Veterinary Journal,v.2,n.162,p.129-140,2001.

79. NIELSEN, L.R. Review of pathogenesis and diagnostic methods of immediate relevance for epidemiology and control of Salmonella Dublin in cattle. Veterinary Microbiology,v.162,n.1,p.1-9,2013.

80. BLANCHARD, P.C. Diagnostics of dairy and beef cattle diarrhea. Veterinary Clinics of North America: Food Animal Practice, v.28, n.3, p.443-464,2012.

81. FEITOSA, F.L. et al. Importância de Cryptosporidium spp. como causa de diarreia em bezerros. Pesquisa Veterinária Brasileira, v.28, n.10, p.452-456,2008.

82. ANDRADE, G.I. et al. Identification of virulence factors by multiplex PCR in Escherichia coli isolated 
from calves in Minas Gerais, Brazil. Tropical Animal Health and Production,v.44, n.7,p.1783-1790, 2012.

83. NASCIMENTO, M.S. et al. Comparação de meios de enriquecimento e de plaqueamento utilizados na pesquisa de Salmonella em carcaças de frango e fezes de aves. Brazilian Journal of Poultry Science, v.2,n.1, p.85-91,2000.

84. SINGH, S. et al. Immunohistochemical and molecular detection natural cases of bovine rotavirus and coronavirus infection causing enteritis in dairy calves. Microbial Pathogenesis, v.138, p.103814,2020.

85. LEAL, M.L.R. et al. Intravenous hypertonic saline solution $(7.5 \%)$ and oral electrolytes to treat of calves with noninfectious diarrhea and metabolic acidosis. Journal of Veterinary Internal Medicine, v.26, n.4, p.1042-1050,2012.

86. NAYLOR, J.M. et al. Advances in oral and intravenous fluid therapy of calves with gastrointestinal disease. In: World Buiatric Congress, 2006, Nice, França.Proceeding... Nice:WBC, 2006.

87. BREGADIOLI, G.D.C. et al. Enteral fluid therapy in neonatal calves and features of commercially available electrolyte solutions in Brazil. Ciência Rural, v.47,n.7,p.e20170140,2017.

88. CONSTABLE, P. Fluid and electrolyte therapy in ruminants. Veterinary Clinics of North America: Food Animal Practice, v.19,n.3,p.557-597,2003.

89. CONSTABLE, P.D. Antimicrobial use in the treatment of calf diarrhea. Journal of Veterinary Internal Medicine,v.18, n.1,p.8-17,2004.

90. GHARIEB, R. et al. Antibiogram, virulotyping and genetic diversity of Escherichia coli and Salmonella serovars isolated from diarrheic calves and calf handlers. Comparative Immunology, Microbiology E Infec- tious Diseases, v.67,p.101367,2019.

91. CONSTABLE, P.D. Treatment of calf diarrhea: antimicrobial and ancillary treatments. Veterinary Clinics of North America: Food Animal Practice, v.25, n.1, p.101-120,2009.

92. FERNANDES, A. et al. Genetic diversity of $\mathrm{BCoV}$ in Brazilian cattle herds. Veterinary Medicine and Science, v.4, n.3, p.183-189, 2018.

93. CRUVINEL, L.B. et al. Prevalence and risk factors for agents causing diarrhea (Coronavirus, Rotavirus, Cryptosporidium spp., Eimeria spp., and nematodes helminthes) according to age in dairy calves from Brazil. Tropical Animal Health and Production, v.52, n.2, p.777-791,2020.

94. BARRINGTON, G.M.; PARISH, S.M. Bovine neonatal immunology. Veterinary Clinics of North America: Food Animal Practice, v.17, n.3, p.463-476, 2001.

95. CHO, Y.I. et al. Case-control study of microbiological etiology associated with calf diarrhea. Veterinary Microbiology, v.166, n.3-4, p.375-385, 2013.

96. AZEVEDO, R.A et al. Padrão ouro de criação de bezerras leiteiras. 2020.1a ed. Gráfica 3P: Uberaba, 30 p.,2020.

97. DYCE, K.M. et al. O aparelho respiratório. In: DYCE, K.M. et al. (2a ed). Tratado de Anatomia Veterinária. Rio de Janeiro: Editora Guanabara Koogan,1997.p.118-132.

98. KLEIN, B.G. Circulação sistêmica e pulmonar. In: KLEIN, B.G. (5 a ed). Cunningham Tratado de Fisiologia Veterinária. Rio de Janeiro: Elsevier, 2014. p. 527-553.

99. CHASE, C.C.L et al. Neonatal immune development in the calf and its impact on vaccine response. 
Veterinary Clinics of North America: Food Animal Practice,v.24, n.1, p.87-104, 2008.

100. DIRKSEN, G. Sistema digestivo, p.166-228. In: DIRKSEN, G. et al. Rosenberger: Exame Clínico dos Bovinos. 3aed. Rio de Janeiro: Guanabara Koogan, 1993.419p.

101. FULTON, R.G. et al. Maternally derived humoral immunity to Bovine Viral Diarrhea Virus (BVDV)1a, BVDV1b, BVDV2, Bovine Herpesvirus1,Parainfluenza-3 Virus Bovine Respiratory Syncytial Virus, Mannheimia haemolytica and Pasteurella multocida in beef calves, antibody decline by half-life studies and effect on response to vaccination. Vaccine, v.22,p.643-649, 2004.

102.SVENSSON, C.; LIBERG, P.The effect of group size on health and growth rate of Swedish dairy calves housed in pens with automatic milk-feeders. Preventive Veterinary Medicine, v.73, n.1,p.43-53, 2006.

103. LAGO, A. et al. Calf respiratory disease and pen microenvironments in naturally ventilated calf barns in winter. Journal of Dairy Science, v.89, n.10, p.4014$4025,2006$.

104. GERSHWIN, L.J. et al. Single pathogen challenge with agents of the bovine respiratory disease complex. PLoS One, v.10, n.11, e0142479, 2015.

105. STÖBER, M. Aparelho respiratório, p.139-165. In: DIRKSEN, G. et al. Rosenberger: Exame Clínico

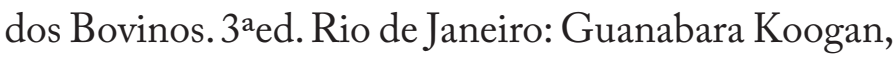
1993.419p.

106. GONÇALVES, R.C. et al. Diferenciação clínica da broncopneumonia moderada e grave em bezerros. Ciência Rural,v.31,n.2,p.263-269, 2001.

106. GONÇALVES, R.C. Semiologia do sistema respiratório, cap.7, p.313-331. In: FEITOSA, F.L.F.
Semiologia Veterinária: A Arte do Diagnóstico. São Paulo: Roca, 2004.

108. LOVE, W.J. et al. Development of a novel clinical scoring system for on-farm diagnosis of bovine respiratory disease in pre-weaned dairy calves. PeerJ, v.2, n.238,p.1-25,2014.

109. BABKINE, M.; BLOND, L. Ultrasonography of the bovine respiratory system and its practical application. Veterinary Clinics of North America: Food Animal Practice,v.25, n.3, p.633-649, 2009.

110. OLLIVETT, T.L. et al. Thoracic ultrasonography and bronchoalveolar lavage fluid analysis in Holstein calves with subclinical lung lesions. Journal of Veterinary Internal Medicine, v.29, n.6, p.1728-1734, 2015.

111. OLLIVETT, T.L.; BUCZINSKI, S. On-Farm use of ultrasonography for bovine respiratory disease. Veterinary Clinics of North America: Food Animal Practice, v.32,n.1, p.19-35,2016.

112. ABUTARBUSH, S.M. et al. Evaluation of the diagnostic and prognostic utility of ultrasonography at first diagnosis of presumptive bovine respiratory disease. Canadian Journal of Veterinary Research, v.76, n.1, p.23-32,2012.

113. OLLIVETT, T.L. Understanding the diagnosis and risk factors for respiratory disease in dairy calves. 2014. 153f. PhD Thesis. University of Guelph, Guelph, ON, Canada.

114. BUCZINSKI, S. et al. Comparison of thoracic auscultation, clinical score, and ultrasonography as indicators of bovine respiratory disease in preweaned dairy calves. Journal of Veterinary Internal Medicine, v.28, n.1,p.234-242,2014.

115. LOVE, W.J.et al. Sensitivity and specificity of onfarm scoring systems and nasal culture to detect bovine 
respiratory disease complex in preweaned dairy calves. Journal of Veterinary Internal Medicine, v.28, n.2, p.119$128,2016$.

116. BUCZINSKI, S. et al. Assessment of dairy calves microbiological environment using Petrifilm bacteriology plates. The Bovine Practitioner, v.51, p.54-58, 2017.

117. ANDRADE, J.P. Métodos de diagnóstico na avaliação pulmonar de bezerros. 2017.76f. Dissertação (Mestrado em Ciência Animal) - Escola de Medicina Veterinária, Universidade Federal de Minas Gerais, Belo Horizonte.

118. COOPER, V.L.; BRODERSEN, B.W. Respiratory disease diagnostics of cattle. Veterinary Clinics of North America: Food Animal Practice, v.26, n.2, p.409416,2010 .

119. O'CONNOR, A.M. et al. A mixed treatment meta-analysis of antibiotic treatment options for bovine respiratory disease - An update. Preventive Veterinary Medicine,v.132,p.130-139,2016.

120. FRANCOZ, D. et al. Evidence related to the use of ancillary drugs in bovine respiratory disease (antiinflammatory and others): Are they justified or not? Veterinary Clinics of North America: Food Animal Practice,v.28, n.1,p.23-38,2012.

121. BICKETT-WEDDLE, D. Development and initial validation of a dairy biological risk management assessment tool. 2009. 214f. Dissertação (Doctor of Philosophy) - Iowa State University, Ames - Iowa.

122. RENAULT, V. et al. Pilot study assessing the possible benefits of a higher level of implementation of biosecurity measures on farm productivity and health status in Belgian cattle farms. Transboundary and Emerging Diseases,v.67,n.2,p.769-777,2019.
123. GODDEN, S.M. et al. Colostrum management for dairy calves. Veterinary Clinics of North America: Food Animal Practice,v.24,n.1,p.19-39,2019.

124. BUCZINSKI, S. et al. Herd-level prevalence of the ultrasonographic lung lesions associated with bovine respiratory disease and related environmental risk factors. Journal of Dairy Science, v.101, n.3, p.2423$2432,2018$.

125. SISCHO, W.M. et al. Cryptosporidia on dairy farms and the role these farms may have in contaminating surface water supplies in the northeastern United States. Preventive Veterinary Medicine, v.43, n.4, p.253-267,2000.

126. SILVERLÅS, C. et al. Prevalence and associated management factors of Cryptosporidium shedding in 50 Swedish dairy herds. Preventive Veterinary Medicine, v.90, n.3-4, p.242-253,2009.

127. PATIENCE, J.F. La calidaddel agua puede ser unfactor de rendimiento. Pig World, Inc. St. Paul, M.N. USA,1992.

128. BRASIL. Ministério da Saúde. Portaria n. ${ }^{\circ}$ 2.914, de 12 de dezembro de 2011. Dispõe sobre normas de potabilidade de água para o consumo humano. Brasília: SVS, 2011.

129. PEGORARO, L.M.C. Biosseguridade na bovinocultura leiteira. Embrapa Clima TemperadoLivro científico. 2018.

130. MADDOX-HYTTEL, C. et al. Cryptosporidium and Giardia in different age groups of Danish cattle and pig's occurrence and management associated risk factors. Veterinary Parasitology, v.141, n.1-2, p.48-59, 2006.

131.MEGANCK, V.et al. Advances in prevention and therapy of neonatal dairy calf diarrhea: a systematical 
review with emphasis on colostrum management and fluid therapy. Acta Veterinaria Scandinavica, v.56, n.1, p.75,2014.

132. KREHBIEL, C.R. Bovine respiratory disease influences on nutrition and nutrient metabolism. Veterinary Clinics of North America: Food Animal Practice, v.36, n.2, p.361-373,2020.

133. CFSPH - Center for Food and Security \& Public Health. The Antimicrobial Spectrum of Disinfectants. 2018.

134. DAMIAANS, B. et al. Perception, motivators and obstacles of biosecurity in cattle production. Vlaams Diergeneeskundig Tijdschrift, v.87, n.3, p.150-163, 2018. 